Cornell University Law School Scholarship@Cornell Law: A Digital Repository

$11-1982$

\title{
Warrantless Vehicle Searches and the Fourth Amendment: The Burger Court Attacks the Exclusionary Rule
}

Steven D. Clymer

Cornell Law School, sdc7@cornell.edu

Follow this and additional works at: https://scholarship.law.cornell.edu/facpub

Part of the Constitutional Law Commons, Fourth Amendment Commons, and the Privacy Law Commons

\section{Recommended Citation}

Clymer, Steven D., "Warrantless Vehicle Searches and the Fourth Amendment: The Burger Court Attacks the Exclusionary Rule" (1982). Cornell Law Faculty Publications. 1611.

https://scholarship.law.cornell.edu/facpub/1611

This Article is brought to you for free and open access by the Faculty Scholarship at Scholarship@Cornell Law: A Digital Repository. It has been accepted for inclusion in Cornell Law Faculty Publications by an authorized administrator of Scholarship@Cornell Law: A Digital Repository. For more information, please contact jmp8@cornell.edu. 


\section{WARRANTLESS VEHICLE SEARCHES AND THE FOURTH AMENDMENT: THE BURGER COURT ATTACKS THE EXCLUSIONARY RULE}

The Supreme Court recently decided three cases in one of the most confusing areas of fourth amendment jurisprudence: warrantless searches of vehicles. ${ }^{1}$ In New York v. Belton, ${ }^{2}$ the Court expanded the authority of an arresting police officer to search the interior of an arrestee's vehicle. On the same day, in Robbins $v$. Califormia, ${ }^{3}$ a plurality of the Court required police officers, even those with authority to conduct a general warrantless search of a vehicle, to obtain warrants in order to search most types of closed containers in the vehicle. Soon after, however, the Court expressed a desire to reconsider Robbins. ${ }^{4}$ In United States v. Ross, ${ }^{5}$ this reconsideration led the Court to overrule Robbins and hold that a police officer with probable cause to search a vehicle may conduct a warrantless search of the vehicle and all containers found in the vehicle. ${ }^{6}$

Warrantless vehicle search decisions like Belton, Robbins, and Ross play a critical role in balancing the concerns of effective law enforce-

1 A majority of the Supreme Court has referred to the law of vehicle searches as "this troubled area." United States v. Ross, 102 S. Ct. 2157, 2168 (1982). Before Ross, a frustrated Justice Powell remarked that "the law of search and seizure with respect to automobiles is intolerably confusing. The Court apparently cannot agree even on what it has held previously, let alone on how . . . cases should be decided." Robbins v. California, 453 U.S. 420 , 430 (1981) (Powell, J., concurring), overnuled, United States v. Ross, 102 S. Ct. 2157 (1982); see also United States v. Rivera, 654 F.2d 1048, 1051 (5th Cir. 1981) ("As Justice Rehnquist once observed, the law governing warrantless searches and seizures, especially those involving vehicles is 'something less than a seamless web.' Eight years later the courts are still trying to extricate themselves from that tangle."), vacaled on other grounds, 684 F.2d 308 (5th Cir, 1982).

As used in this Note, the term "vehicle searches" refers to searches of vehicles, their occupants, and their contents.

2453 U.S. 454 (1981); see infra notes $144-65$ and accompanying text.

3453 U.S. 420 (1981) (plurality opinion), overruled, United States v. Ross, 102 S. Ct. 2157 (1982); see infra notes 77-89 and accompanying text.

4 When the Court granted certiorari in Ross, it directed the parties "to address the question whether the Court should reconsider Robbins . . . " United States v. Ross, 454 U.S. 891 (1981).

$5102 \mathrm{~S}$. Ct. 2157 (1982); see infra notes 114-43 and accompanying text.

6 . For a discussion of the recent decisions, see generally Wainger, The Warrant Requirement for Container Searches and the "Well-Delineated" Exceptions: The New "Bright Line" Rules, 36 U. Miam L. Rev. 115 (1981); Comment, Robbins and Belton: Inconsistency and Confusion Continue to Reign Supreme in the Area of Vehicle Searches, 19 Hous. L. REv. 527 (1982); Comment, Search and Seizure of Containers Found in Automobiles: The Supreme Court Struggles for a "Bright Line" Rule, 16 U. RICH. L. REV. 649 (1982); authorities cited infra notes 114, 144. 
ment and individual privacy. ${ }^{7}$ Uncertainty about the constitutionality of a warrantless search may lead police either to forego a legitimate search or to violate an individual's privacy rights. When police do conduct an unconstitutional search, whether intentionally or accidentally, ${ }^{8}$ the fourth amendment exclusionary rule mandates the exclusion of the illegally obtained evidence at trial. ${ }^{9}$ Because the costs of uncertainty are so great, ${ }^{10}$ rules that are easily applied to a variety of situations are essential. ${ }^{11}$ The Supreme Court's vehicle search decisions, however, have often confused rather than clarified the law. ${ }^{12}$

The recent decisions governing warrantless searches of vehicles and their contents reveal that the Burger Court is struggling to simplify a confusing area of law. Ironically, this Court's departure from traditional exigency-based approaches to vehicle searches has caused much of the confusion. Instead of the traditional approaches, the Court has offered new justifications for warrantless searches and "bright line" rules to guide police. These rationales have proved unsatisfactory. The new justifications are illogical and unconvincing; the "bright-line" rules shift confusion from one area to another. Furthermore, the Court's treatment of vehicle searches has led to unnecessary intrusions on the privacy interests of vehicle users. The Court's approach is not the result of hostility toward simplicity, logic, or individual rights. Rather, it is a manifestation of the Court's reluctance to apply the exclusionary rule as the remedy for violations of fourth amendment rights.

7 When a police officer searches a vehicle, the vehicle's occupant has three interests at stake: "an interest in moving on, an interest in control over his property, and an interest in the secrecy of the car's contents." Note, Warraniless Searches and Seizures of Automobiles, 87 HARV. L. REV. 835, 841 (1974).

8 Some courts have concluded that the exclusionary rule does not apply when a police officer acts reasonably and in good faith. See infra notes 9, 252. The Supreme Court has granted certiorari to consider a "good faith" exception to the fourth amendment exclusionary rule. See Illinois v. Gates, cert. granted, 103 S. Ct. 436 (1982).

9 The judicially created exclusionary rule requires courts to exclude at trial all evidence that police obtain by means that violate the fourth amendment. See Weeks v. United States, 232 U.S. 383, 398 (1914). The Supreme Court has extended the rule to the states. See Mapp v. Ohio, 367 U.S. 643,655 (1961) (plurality opinion). For further discussion of the exclusionary rule, see infra notes 248-52 and accompanying text. The Court's expressed rationale for the sanction of the exclusionary rule is that it will deter police from conducting unconstitutional searches. See Mapp, 367 U.S. at 656.

10 Although opponents of the exclusionary rule criticize its severity, recent studies show that courts rarely suppress evidence. See Y. KaMisar, W. LAFAVE \& J. IsRaEL, MODERN Criminal Procedure 221 n.c (5th ed. 1980).

11 See, e.g., United States v. Ross, 102 S. Ct. 2157, 2161 (1982) ("There is . . . no dispute among judges about the importance of striving for clarification in this area of the law."); LaFave, "Case-by-Case Adjudieation" Versus "Standardized Procedures": The Robinson Dilemma, 1974 SuP. CT. REV. 127, 141.

12 See supra note 1. 


\section{The Development of the Law of WarRantless VEHICLE SEARCHES}

Although the text of the fourth amendment proscribes only "unreasonable" searches, ${ }^{13}$ the Supreme Court has long held that warrantless searches, except those falling within a small group of exceptions, ${ }^{14}$ are unreasonable per se and thus unconstitutional. ${ }^{15}$ Among these exceptions to the warrant requirement are the "automobile exception"16 and

13 The fourth amendment provides:

The right of the people to be secure in their persons, houses, papers, and effects, against unreasonable searches and seizures, shall not be violated, and no Warrants shall issue, but upon probable cause, supported by Oath or affirmation, and particularly describing the place to be searched, and the persons or things to be seized.

U.S. Const. amend. IV; see also Robbins v. California, 453 U.S. 420, 438 (1981) (Rehnquist, $\mathrm{J}$., dissenting) ("[N]othing in the Fourth Amendment itself requires that searches be conducted pursuant to warrants. The terms of the Amendment simply mandate that the people be secure from unreasonable searches and seizures . . . '), overruled, United States v. Ross, 102 S. Ct. 2157 (1982).

14 The principal exceptions to the warrant requirement are: search incident to arrest, see, e.g., Chimel v. California, 394 U.S. 752 (1969); the automobile exception, see, e.g., Chambers v. Maroney, 399 U.S. 42 (1970); consent, see, e.g., Schneckloth v. Bustamonte, 412 U.S. 218 (1973); plain view, see, e.g., Harris v. United States, 390 U.S. 234 (1968) (per curiam); hot pursuit, see, e.g., Warden v. Hayden, 387 U.S. 294 (1969); stop and frisk, see, e.g., Terry v. Ohio, 392 U.S. 1 (1968); emergency, see, e.g., Michigan v. Tyler, 436 U.S. 499 (1978); and prevention of loss or destruction of evidence, see, e.g., Schmerber v. California, 384 U.S. 757 (1966). See generally Comment, The Automobile Exception: A Contradiction in Fourth Amendment Principles, 17 SAN Diego L. Rev. 933, 933-34 nn.1-10 (1980).

15 See, e.g., Mincey v. Arizona, 437 U.S. 385, 390 (1978). The Supreme Court imposes the warrant requirement because an "officer engaged in the often competitive enterprise of ferreting out crime" is unable to assess impartially the existence of probable cause to search. Thus, the Court prefers that a "neutral and detached magistrate" make that determination. See Johnson v. United States, 333 U.S. 10, 14 (1948). The warrant requirement also requires a pre-search review of the existence of probable cause, preventing "hindsight from coloring the evaluation of the reasonableness of a search or seizure." United States v. Ross, $102 \mathrm{~S}$. Ct. 2157, 2175 (1982) (Marshall, J., dissenting) (quoting United States v. Martinez Fuerte, 428 U.S. 543, 565 (1976)). The warrant requirement applies to the states. See Ker v. California, 374 U.S. 23, 33 (1963).

16 For a trcatment of the "automobile exception," see generally 2 W. LAFAVE, SEARCH AND SEIzURE 508-44 (1978); Wilson, The Warranlless Automobile Search: Exception Withoul Justificalion, 32 Hastings L.J. 127 (1980); Note, Warranlless Conlainer Searches Under the Aulomobile and Search Incident Exceptions, 9 FORDHAM URB. L.J. 185 (1980); Note, supra note 7; Comment, Warrantless Searches and Seizures of Automobiles and the Supreme Court from Carroll to Cardwell: Inconsistently Through the Seamless Web, 53 N.C.L. Rev. 722 (1975); Comment, supra note 14; Note, The Automobile Exception to the Warrant Requirement: Speeding Away From the Fourth Amendment, 82 W. VA. L. REV. 637 (1980). The term "automobile exception" is misleading because courts have also applied the exception to searches of other vehicles. See, e.g., United States v. Olson, 670 F.2d 185 (11th Cir. 1982) (unpublished opinion) (airplane); United States v. Harris, 627 F.2d 474, $475-76$ (D.C. Cir.), cert. denied, 453 U.S. 912 (1980) (van); United States v. Hudson, 601 F.2d 797, 800 (5th Cir. 1979) (motor home); 2 W. LAFAVE, supra, at $508 \mathrm{n} .2$ (citing cases). The Supreme Court has granted certiorari in a case in which the state of Florida has contended that a warrantless search of the hold of a boat is valid under the 
the "search-incident-to-arrest" exception, ${ }^{17}$ which courts frequently apply to allow the admission of evidence that police obtain by conducting warrantless vehicle searches. ${ }^{18}$ Traditionally, the Supreme Court has construed narrowly exceptions to the warrant requirement. ${ }^{19}$

\section{A. The Automobile Exception}

\section{Pre-Burger Court Developments}

Until recently, the Supreme Court did not articulate an "automobile exception" to the warrant requirement. ${ }^{20}$ Rather than treating automobiles as a distinct area of fourth amendment analysis, the Court condoned warrantless searches of vehicles and other areas only in exigent circumstances. ${ }^{21}$

In Carroll v. United States, ${ }^{22}$ decided in 1925, the Supreme Court first considered the constitutionality of a warrantless vehicle search. In Carroll, federal agents had probable cause to search Carroll's vehicle ${ }^{23}$ but,

automobile and search-incident-to-arrest exceptions. See Florida v. Casal, cert. granted, 103 S. Ct. 50 (1982).

17 For a treatment of the search-incident-to-arrest exception in the context of vehicle searches, see generally 2 W. LAFAVE, supra note 16, at 598-608; Note, supra note 16, 9 FORDHAM URB. L.J. 185; Note, Criminal Law: The Effect of Chimel v. California on Automobile Search and Seizure, 23 OKLA. L. Rev. 447 (1970); Comment, Chimel v. California: A Potential Roadblock to Vehicle Searches, 17 U.C.L.A. L. REV. 626 (1970). Courts have also applied the searchincident-to-arrest exception to vehicles other than automobiles. See, e.g., United States v. Wiga, 662 F.2d 1325, 1332 (9th Cir. 1981) (motor home), cert. denied, 102 S. Ct. 1775 (1982); United States v. Thomas, 536 F. Supp. 736, 743 (M.D. Ala. 1982) (airplane). When police arrest the occupant of a vehicle considerably larger than an automobile, courts may apply the "protective sweep" variation of the search-incident-to-arrest exception. This rule allows police to conduct a warrantless vehicle search for accomplices, but not for weapons or evidence. See, e.g., United States v. Wiga, 662 F.2d 1325, 1332 (9th Cir. 1981), cert. denied, 102 S. Gt. 1775 (1982).

18 This Note focuses on two exceptions to the warrant requirement that courts frequently apply to uphold warrantless vehicle searches: the "automobile exception" and the search-incident-to-arrest exception. See supra notes 16,17. These exceptions are not mutually exclusive; both may apply to a given fact situation. If a police officer mistakenly believes that a particular exception validates a warrantless search, the search is constitutional if another exception applies. See Scott v. United States, 436 U.S. 128, 136 (1978). The Supreme Court has also allowed warrantless vehicle searches on other grounds. See, e.g., South Dakota v. Opperman, 428 U.S. 364 (1976) (inventory search); Cady v. Dombrowski, 413 U.S. 433 (1973) (warrantless search of injured police officer's car to remove weapon believed to be loeated there). See generally 2 W. LAFAVE, supra note 16, at 563; Comment, supra note 16.

19 See, e.g., Arkansas v. Sanders, 442 U.S. 753, 759-60 (1979), limiled on other grounds, United States v. Ross, 102 S. Ct. 2157 (1982); Mincey v. Arizona, 437 U.S. 385, 393-94 (1978).

20 In Coolidge v. New Hampshire, 403 U.S. 443, 462 (1971) (plurality opinion), a Supreme Court opinion used the term "automobile exception" for the first time. A majority of the Court first used the term in United States v. Chadwick, 433 U.S. 1, 5 (1977).

21 The Supreme Court has held that warrantless searches conducted by police in other exigent circumstances are constitutional. See, e.g., Michigan v. Tyler, 436 U.S. 499 (1978); Warden v. Hayden, 387 U.S. 294 (1969).

22267 U.S. 132 (1925).

23 Id. at 160. The federal agents had previous dealings with the vehicle's occupants and knew that they were involved in Prohibition violations. See id.; see also United States v. Ross, 
because they could not lawfully detain its occupants, ${ }^{24}$ the agents had to conduct an immediate warrantless search or risk allowing the suspects to drive the vehicle out of the jurisdiction before the agents could obtain a warrant. ${ }^{25}$ The agents conducted the search and discovered contraband liquor that led to the convictions of the vehicle's occupants. The Supreme Court upheld the convictions. ${ }^{26}$

The Carroll doctrine delineated two constitutional requirements for a warrantless vehicle search. First, the law enforcement officials needed probable cause to search the vehicle. ${ }^{27}$ Second, the Court required a genuine threat that someone would move the vehicle before the officials could obtain a search warrant. Thus "[i]n cases where the securing of a warrant is reasonably practicable, it must be used. . . ."28 In short, Carroll required both probable cause and exigency. ${ }^{29}$

102 S. Ct. 2157, 2162 n.5 (1982). In Carroll, Justice McReynolds challenged the finding of probable cause. See 267 U.S. at 171 (McReynolds, J., dissenting).

24 The agents did not see the vehicle's occupants commit a crime and, because the suspected violation was a misdemeanor, the officers could not make an arrest. See Carroll, 267 U.S. at 137; see also United States v. Ross, 102 S Ct. 2157, 2178 n.6 (1982) (Marshall, J., dissenting); 2 W. LAFAVE, supra note 16, at 511 ("[T]he occupants of the car were not arrested prior to the actual discovery of the [contraband] liquor and apparently could not have been arrested.").

25 "[I]t is not practicable to secure a warrant because the vehicle can be quickly moved out of the locality or jurisdiction in which the warrant must be sought." 267 U.S. at 153.

26 The Court affirmed the trial court's denial of a motion for the return of the seized evidence. See id. at 162.

27 Id. at 156. For a discussion of the concept of probable cause, see generally $1 \mathrm{~W}$. LAFAVE, supra note 16 , at $437-716$.

28267 U.S. at 156 . Lower courts also construed the practicability requirement to proscribe warrantless vehicle searches in cases in which probable cause existed sufficiently in advance of the search to make the acquisition of a warrant reasonable. See $2 \mathrm{~W}$. LAFAvE, supra note 16, at 519-25, and cases cited therein. A plurality of the Court rejected this interpretation in Cardwell v. Lewis, 417 U.S. 583, 595 (1974) (plurality opinion). See infra note 54.

29 Cf. Coolidge v. New Hampshire, 403 U.S. 443, 458, 460 (1971) (plurality opinion) (officers with probable cause may conduct warrantless vehicle search if threat of mobility exists); United States v. Preston, 376 U.S. 364, 368 (1964) (Carroll inapplicable absent threat of mobility); Comment, supra note 16, at 727; Comment, supra note 14, at 938; Note, supra note 16,82 W. VA. L. REV. at 638.

Some members of the Court have construed Carroll as limited to searches for contraband, see Chambers v. Maroney, 399 U.S. 42, $62-63$ n.7 (1971) (Harlan, J., concurring and dissenting), or to searches authorized by statute, see United States v. DiRe, 332 U.S. 581, 586-87 (1948). See also Note, supra note 7, at 839 n.24.

This Note's interpretation of Carroll varies considerably from that of the Supreme Court in United States v. Ross, 102 S. Ct. 2157, 2162-64 (1982). The Ross Court interpreted Carroll to allow disparate treatment of vehicles. To support its interprctation, the Court relied on legislation passed shortly after the drafting of the fourth amendment that allowed customs officials to conduct warrantless vehicle searches based on probable cause alone. See id. at 2162 n.6. The Court inferred from this legislation that the fourth amendment accords vehicles diminished protection. The Court's reasoning is suspect. Beeause the legislation pertained to searches by customs officials, the absence of a warrant requirement may well have been predieated upon the fact that the vehicles were crossing the border. See id. at 2163 n.7. The Court has recognized the government's need to conduct searches and stops at its borders. See, e.g., United States v. Brignoni-Ponce, 422 U.S. 873, 878 (1975). Thus, the legislation may have 
The Warren Court never applied the Carroll doctrine to uphold a warrantless vehicle search. ${ }^{30}$ In Preston 0 . United States, ${ }^{31}$ a unanimous Warren Court rejected the contention that Carroll allowed police to search a car after arresting its occupants and taking the vehicle into custody. "[S]ince the men were under arrest at the police station and the car was in police custody . . . [there was no] danger that the car would be moved out of the locality or jurisdiction." 32 As in Carroll, the Preston Court required proof of exigency before validating a warrantless search. ${ }^{33}$

Before 1970, courts relied almost exclusively on the search-incidentto-arrest exception, rather than Carroll, to uphold warrantless vehicle searches. ${ }^{34}$ When the Supreme Court limited the scope of the search-

indicated an understanding that customs officials may conduct warrantless searches of vehicles crossing the border, not that police may routinely conduct warrantless searches of all vehicles.

30 But of. Cooper v. California, 386 U.S. 58 (1967). In Cooper, the Warren Court held constitutional a warrantless search of an automobile that police had seized and impounded pending forfeiture proceedings. The Court distinguished the case before it from Preston v. United States, 376 U.S. 364 (1964), see infra notes 31-33, by asserting that the police in Cooper had held the vehicle as evidence. 386 U.S. at 61 . In Cooper, state law required the police to hold the car. "It would be unreasonable," the Court concluded, "to hold that the police, having to retain the car in their custody for such a length of time, had no right, even for their own protection, to search it." Id. at 61-62.

31376 U.S. 364 (1964). In Preston, police arrested the occupants of a parked car for vagrancy. After driving the car to the police station and towing it to a parking lot, police searched the vehicle without a warrant. They discovered evidence that led to the arrestees' convictions for conspiracy to rob a federally insured bank. Id. at 365-66. The Supreme Court ruled that the search violated the fourth amendment. See id. at 368 .

32 Id. at 368.

33 Later opinions have interpreted Preston differently. $\dot{S}_{e e}$ Cady v. Dombrowski, 413 U.S. 433, 444 (1973) (Preston "stands only for the proposition that the search challenged there could not be justified as one incident to an arrest."); Chambers v. Maroncy, 399 U.S. 42, 47 (1970) (police lacked probable cause to conduct search in Preston); Cooper v. California, 386 U.S. 58, 61 (1967) (search in Preston unconstitutional because unrelated to arrest). The language of Preston, however, illustrates that the Court refused to apply Carroll because no one was likely to move the vehicle: "[S]ince the men were under arrest at the police station and the car was in police custody . . . [there was no] danger that the ear would be moved out of the locality or jurisdiction." 376 U.S. at 368. Accord Chambers v. Maroney, 399 U.S. 42, 6465 (1970) (Harlan, J., dissenting).

34 The Court, however, did apply Carroll to uphold warrantless vehicle searches that preceded arrests. See, e.g., Brinegar v. United States, 338 U.S. 160, 165, 177-78 (1949); Scher v. United States, 305 U.S. 251, 253-55 (1938); Husty v. United States, 282 U.S. 694, 701 (1931). Nevertheless, when police arrested suspects before conducting a search, thereby removing the exigency required by Carroll, courts relied upon the search-incident-to-arrest exception. See, e.g., Lee v. United States, 376 F.2d 98, 100-01 (9th Cir.) (search of automobile lawful as incident to arrest), cert. denied, 389 U.S. 837 (1967); Harris v. Stephens, 361 F.2d 888, 893 (8th Cir. 1966) (search of automobile in driveway constitutional as incident to arrest of defendant at front door), cert. denied, 386 U.S. 964 (1967); Jefferson v. United States, 349 F.2d 714, 715 (D.C. Cir. 1965) (per curiam) (search of car trunk upheld as incident to arrest); see also Moylan, The Automobile Exception: What It Is and What It Is Not. . . A Rationale In Search of a Clearer Label, 27 Mercer L. REv. 987, 1000-01 (1976). 
incident-to-arrest exception in Chimel v. Califormia, ${ }^{35}$ however, "the continuing vitality and potential reach of the Carroll doctrine suddenly become important."36

\section{The Burger Court-Searches of Vehicles.}

The Burger Court first considered the Carroll doctrine in Chambers v. Maroney. ${ }^{37}$ In Chambers, state police officers ${ }^{38}$ conducted a warrantless search of an automobile that they had driven to the police station after arresting the occupants for armed robbery. ${ }^{39}$ The Supreme Court held that Carroll authorized the search. ${ }^{40}$ Although the Chambers Court retained the probable cause requirement of the Carroll doctrine, ${ }^{41}$ the Court effectively eviscerated the second requirement that the circumstances surrounding the search pose an actual threat of mobility. Unlike the federal agents in Carroll, the police in Chambers had both the defendants and the vehicle in custody at the time of the search, thus eliminating any threat of mobility while police sought a search warrant. ${ }^{42}$ Nevertheless, the majority treated the search as necessary to prevent an arrestee or a confederate from moving the automobile before police could obtain a search warrant. ${ }^{43}$ The threat of mobility was a fictitious

\footnotetext{
35395 U.S. 752 (1969); see infra notes 98-104 and accompanying text.

362 W. LAFAVE, supra note 16 , at 512 .

37399 U.S. 42 (1970).
}

38 Before Chambers, the Supreme Court had not applied the Carroll doctrine to a search conducted by state law enforcement officers. For a discussion of the differences between federal and state law enforcement officers conducting vehicle searches, see generally Cady v. Dombrowski, 413 U.S. 433, 440-41 (1973); Comment, supra note 16, at 729-30. The Court has never held that differences between federal and state law enforcement activities require different fourth amendment treatment.

39399 U.S. at 44. Before Chambers, the Supreme Court had not applicd Carroll to a search conducted after an arrest. See supra note 34 .

40 See 399 U.S. at 52.

. 41 See id. at 51.

42 See id. at 44.

43 For constitutional purposes, we sce no difference between on the one hand seizing and holding a car before presenting the probable cause issue to a magistrate and on the other hand carying out an immediate search without a warrant. Given probable cause to scarch, either course is reasonable under the Fourth Amendment.

On the facts before us, the blue station wagon could have been searched on the spot when it was stopped since there was probable eause to search and it was a fleeting target for a search. The probable-cause factor still obtained at the station house and so did the mobility of the car unless the Fourth Amendment permils a warrontless seizure of the car and the denial of its use to anyone until a warrant is secured. In that event there is little to choose in terms of practical consequences betwcen an immediale search without a warrant and the car's immobilization until a warrant is obtained.

Id. at 52. (emphasis added) (footnote omitted). The Court's reference to an "immediate" search at a station house after the arrest is comprehensible only if one assumes that an arrestee or confederate sought access to the vehicle while the vehicle was in police custody. Taken in that sense, the threat that someone would move the vehicle creates the immediacy. "Immediate" in the context of Chambers does not mean "as soon as police stopped the vchicle." 
one, however, in that the Court did not assert that anyone actually sought to move the vehicle while it was in police custody. Thus, although purporting to follow Carroll, the Chambers Court allowed a warrantless search based on probable cause alone. ${ }^{44}$ The Court's use of the fiction left the vitality of the Carroll doctrine's exigency requirement unclear.

In Coolidge v. New Hampshire, ${ }^{45}$ a plurality of the Court further obfuscated the doctrine by refusing to hold that probable cause alone validated a warrantless ${ }^{46}$ vehicle search. Instead of providing a principled basis for its holding that a post-arrest seizure and search of an automobile on the arrestee's driveway was unconstitutional, the plurality merely enumerated distinctions between Coolidge and earlier vehicle search decisions. ${ }^{47}$ The plurality concluded that the search was uncon-

Accord Note, supra note 7, at 844 . Thus, the Court's analysis in Chambers presupposes that someone sought to move the vehicle.

44 Justice Harlan, in dissent, criticized the majority for abandoning the exigency requirement. See 399 U.S. at 62-63 (Harlan, J., dissenting); see also Wilson, supra note 16, at 129 ("pretext of exigency"); Comment, supra note 16, at 737 ("Chambers seems to have modified the Carroll doctrine so that the . . . potential mobility of an automobile . . . justif[ies] an unwarranted search."). The language of Chambers, however, is contrary to such an expansive interpretation: "Neither Carroll nor other cases in this Court require or suggest that in every conceivable circumstance the search of an auto even with probable cause may be made without the extra protection for privacy that a warrant affords." 399 U.S. at 50. Yet, despite this language, it is difficult to conceive of circumstances in which a principled application of Chambers would not condone a warrantless vehicle search based on probable cause alone.

45403 U.S. 443 (1971) (plurality opinion). In Coolidge, police arrested Coolidge at his home in connection with a murder. Two and a half hours later, after refusing to allow Mrs. Coolidge to use the family cars, the police had them towed from Coolidge's driveway to the police station. Id. at 447. Two days later, police searched the cars and discovered evidence that they used to secure Coolidge's conviction. Id. at 448 .

46 The police had obtained a search warrant from the State Attorney General, who was involved in the investigation. But, because the Attorney General was not a "neutral and detached magistrate required by the Constitution, the search [stood] on no firmer ground than if there had been no warrant at all." Id. at 453.

47 The plurality supplied a number of reasons for concluding that Carroll and Chambers did not justify the search. First, "the police had known for some time of the probable role of the [defendant's] car in the crime." Id. at 460 . The Court thus suggested that the police had an opportunity to obtain a warrant before conducting the search. But this reason appears spurious because the police had obtained what they believed to be a valid warrant before searching the vehicle. Id. at 453 ; see supra note 46 . Furthermore, in a later case, a plurality of the Court concluded that a prior opportunity to obtain a warrant does not render a warrantless vehicle seizure unconstitutional. See Cardwell v. Lewis, 417 U.S. 583, 595 (1974) (plurality opinion); infra note 54 . Second, the Coolidge plurality noted that the defendant had ample opportunity to destroy any incriminating evidence. See 403 U.S. at 460 . This indicated a lack of probable cause to search the vehicle. But see id. at 464 ("Here there was probable cause ..."). Third, the defendant was not using the car for an illegal purpose at the time of the search. Id. at 460 . But see Cardwell v. Lewis, 417 U.S. 583, 585 (1974) (plurality opinion) (upholding conviction based on a warrantless seizure and examination of exterior of a vehicle even though the defendant was not using the vehicle for an illegal purpose at the time of the seizure). Fourth, the objects sought "were neither stolen nor contraband nor dangerous." 403 U.S. at 460 . But see Cardwell v. Lewis, 417 U.S. 583, 585 (1974) (plurality opinion) (upholding conviction based on a warrantless seizure and examination of exterior of a vehicle despite 
stitutional because "no exigent circumstances justified the police in proceeding without a warrant,"48 a remark seemingly at odds with Chambers. ${ }^{49}$

Three years after Coolidge, in Cardwell v. Lewis, ${ }^{50}$ a plurality of the Court, having concluded that a police examination of the exterior of a vehicle did not constitute a "search," 11 nonetheless continued to erode the Carroll doctrine by emphasizing a justification for warrantless vehicle searches distinct from exigency. Despite mentioning that "[a]n underlying factor in the Carroll-Chambers line of decisions has been the exigent circumstances that exist in connection with movable vehicles,"52 the plurality focused on the "lesser expectation of privacy" that people have in vehicles as opposed to residences. ${ }^{53}$ The Court reasoned that these

the absence of contraband, stolen or dangerous objects). Fifth, neither Coolidge nor his wife could have gained access to the vehicle. 403 U.S. at 460-61. Thus, the Coolidge plurality, unlike the Chambers majority, refused to fabricate a thrcat of mobility and instead considered the actual exigencies in the case. Finally, the vehicle was unoccupied and on private property. Id. at $463 \mathrm{n} .20$. For a discussion of the significance of this conclusion, see infra notes 24347 and accompanying text.

48403 U.S. at 464.

49 See supra note 44 and accompanying text. A plurality of the Court has adopted a narrow interpretation of Coolidge. See Cardwell v. Lewis, 417 U.S. 583, 593 (1974) (plurality opinion) (Coolidge prevented warrantless seizure of automobile located on private property).

50417 U.S. 583 (1974) (plurality opinion). After arresting Lewis in connection with a murder committed with a car, police, without a warrant, seized his car from a public parking lot. The prosecution used evidence that police obtained in a warrantless examination of the exterior of the vehicle in order to obtain a conviction. Lewis lost on appcal, see id. at 585, but successfully petitioned a federal district court for a writ of habeas corpus. Lewis v. Cardwell, 354 F. Supp. 26 (S.D. Ohio 1972). After the court of appcals affirmed, Lewis v. Cardwell, 476 F.2d 467 (6th Cir. 1973), the Supreme Court reversed. 417 U.S. at 596.

51417 U.S. at 588-89. The four dissenters questioned this conclusion and considered it irrelevant, arguing that the police action was also an unconstitutional seizure. Id. at 597 . Justice Powell, concurring in the result, did not consider the merits. Id. at 596.

52 Id. at 590.

53 See id. The Cardwell plurality apparently relied on the "reasonable expectation of privacy" analysis proposed in Justice Harlan's concurring opinion in Katz v. United States, 389 U.S. 347 (1967). Harlan believed that police activities infringing upon an individual's protected expectations of privacy violate the fourth amendment. He described his test for determining whether an expection was protected as a "twofold requirement, first that a person have exhibited an actual (subjective) expectation of privacy and, second, that the expectation be one that society is prepared to recognize as 'rcasonable." "Id. at 316 (Harlan, J., concurring). Harlan considered all intrusions on such protected expectations of privacy as violations of the fourth amendment. In Smith v. Maryland, 442 U.S. 735, 740-41 (1979), a majority of the Court adopted this "monolithic" approach. See Amsterdam, Perspectives on the Fourth Amendment, 58 MiN. L. REV. 349, 388 (1974).

In contrast to this "monolithic" approach, the Burger Court's automobile exception suggests a movement toward a "sliding scale" approach to the fourth amendment. Rather than concluding that the presence or absence of rcasonable privacy expectations determines the application or nonapplication of the fourth amendment, the Court has held that one aspect of the fourth amendment, the warrant requirement, does not apply when people have lesser expectations of privacy. In order to prevent this inquiry into relative privacy expectations from converting "the fourth amendment into one immense Rorschach blot," Amsterdam, supra, at 393 , the Court has had to generalize its diminished expectations of privacy analysis 
diminished expectations of privacy justify diminished fourth amendment protection. ${ }^{54}$

In Texas v. White, ${ }^{55}$ decided a year after Cardwell, the Court eradicated any remaining vestige of the Carroll doctrine's exigency requirement. In a per curiam opinion, the Court held that a warrantless search of a vehicle was constitutional because the police who conducted the search had probable cause to believe that the vehicle contained evidence of a crime; 5 the Court did not consider the actual mobility of the vehicle.

Having abandoned exigency as a rationale for allowing warrantless vehicle searches based on probable cause, the Burger Court has advanced other reasons to support its treatment of these cases. First, the Court has asserted that people have lesser expectations of privacy in vehicles than they do in residences and closed containers. ${ }^{57}$

Second, the Court has stressed the "inherent mobility" of automobiles. Although the Court has indicated that "inherent mobility" alone is not sufficient to justify warrantless searches, ${ }^{58}$ it has con-

by assuming that people always have lesser privacy expectations in automobiles. See infra notes 209, 213 and accompanying text.

54 Although the Cardwell plurality's reliance on privacy expectations was of questionable precedential value because the plurality did not consider the police activity to be a "search," see supra note 51 and accompanying text, a majority of the Court later embraced the plurality's reasoning. See, e.g., Arkansas v. Sanders, 442 U.S. 753, 761 (1979), limiled on other grounds, United States v. Ross, 102 S. Ct. 2157 (1982); United States v. Martinez-Fuerte, 428 U.S. 543, 561 (1976). The Cardwell plurality found that individuals have lesser expectations of privacy in automobiles because an automobile's "function is transportation and it seldom serves as one's residence or as the repository of personal effects. A car has little capacity for eseaping public scrutiny. It travels public thoroughfares where both its occupants and its contents are in plain view." 417 U.S. at 590. The Court later reasoned that an automobile's exposure to governmental regulation diminishes the privacy expectations of its occupants. See United States v. Chadwick, 433 U.S. 1, 12-13 (1977).

The Cardwell Court also rejected the position that a prior opportunity to obtain a search warrant renders a later warrantless search unconstitutional. See 417 U.S. at 595-96. In Cardwell, police had suspected for over two months before they seized the defendant's vehicle that the defendant had used his car to commit a crime. See id. at 586-87. Thus, it appears that Carroll, to the extent that it required a warrant when "reasonably practicable," see supra note 28 and accompanying text, did not survive Cardwell: Surely it was reasonably practicable for police to obtain a search warrant in the two months preceding the arrest.

55423 U.S. 67 (1975) (per curiam). Police arrested White while he was trying to cash fraudulent checks at a drive-through window of a bank. An officer drove White's car to the police station, where police conducted a warrantless search and uncovered four checks that the trial court later admitted into evidence.

56 See id. at 68; Note, supra note 16,82 W. VA. L. Rev. at 651 ("After White, it appeared that for all practical purposes all that was needed to validate a warrantless search or seizure of an automobile was probable cause."); see also Michigan v. Thomas, 102 S. Ct. 3079 (1982) (per curiam) (probable cause justified warrantless vehicle scarch); Colorado v. Bannister, 449 U.S. 1 (1980) (per curiam) (police officer with probable cause to believe that objects in a car were stolen could seize those objects without a warrant).

57 See supra notes 53-54 and accompanying text.

58 See Robbins v. California, 453 U.S. 420, 424 (1981) (plurality opinion), overruled on other grounds, United States v. Ross, 102 S. Ct. 2157 (1982). 
cluded that "[o]ur treatment of automobiles has been based in part on their inherent mobility ." 59 "

Third, the Court has focused on the administrative burdens that the detention of vehicles pending issuance of a warrant would impose on law enforcement agencies. ${ }^{60}$ If the Court were to proscribe warrantless vehicle searches, it would force police either to leave a vehicle where they stopped it or to seize and hold the vehicle until a magistrate issued a search warrant. ${ }^{61}$ The first alternative threatens evidence by subjecting the vehicle to theft or intrusion. The second alternative requires that police departments provide "the people and equipment necessary to transport impounded automobiles to some central location [and maintain an] . . . appropriate location where [the vehicles] could be kept, with due regard to the safety of the vehicles and their contents."62 The Court has apparently concluded that both of these alternatives unduly burden police, and thus allows warrantless vehicle searches based on probable cause alone.

\section{The Burger Court-Searches of Containers In Vehicles}

Having concluded that the automobile exception applies whenever police have probable cause to search a vehicle, the Burger Court recently considered the scope of this exception. Specifically, the Court considered whether a police officer's authority to conduct a warrantless vehicle search based on probable cause authorizes him to search closed containers in the vehicle. 63

In Arkansas $v$. Sanders, ${ }^{64}$ the Court considered the constitutionality of

59 United States v. Chadwick, 433 U.S. 1, 12 (1977); see Michigan v. Thomas, 102 S. Ct. 3079,3081 (1982) (per curiam) ("It is thus clear that the justification to conduct [a warrantless vehicle search] does not vanish once the car has been immobilized. . . ."); Robbins v. California, 453 U.S. 420, 440 (1981) (Rehnquist, J., dissenting) (emphasis in original), overnuled on other grounds, United States v. Ross, 102 S. Ct. 2157 (1982):

$[O]$ ne need nol demonstrate that a particular automobile was capable of being moved, but that automobiles as a class are inherently mobile, and a defendant seeking to suppress evidence obtained from an automobile should not be heard to say that this particular automobile had broken down, was in a parking lot under the supervision of the police, or the like.

60 See, e.g., Arkansas v. Sanders, 442 U.S. 753, 763 n.10, 765-66 n.14 (1979), limiled on other grounds, United States v. Ross, 102 S. Ct. 2157 (1982).

61 See id. at 765-66 n.14. The acquisition of a search warrant by telephone is another alternative. See Note, Warrantless Automobile Searches and Telephonic Search Warranls: Should the "Automobile Exception" Be Redrawn?, 7 Hastings Const. L.Q. 1031 (1980).

62442 U.S. at $765-66$ n.14.

63 Sec, e.g., United States v. Ross, 102 S. Ct. 2157 (1982); Robbins v. California, 453 U.S. 420 (1981) (plurality opinion), overnuled, United States v. Ross, 102 S. Ct. 2157 (1982); Arkansas v. Sanders, 442 U.S. 753 (1979), limiled, United States v. Ross, 102 S. Ct. 2157 (1982).

64442 U.S. 753 (1979), limiled, United States v. Ross, 102 S. Ct. 2157 (1982). Police, acting upon probable cause that Sander's suitcase contained marihuana, stopped the taxicab in which he was travelling. The taxi driver opened the trunk, where the suitcase was located, and the police opened the suitcase, which contained marihuana. The trial court admitted this evidence, 442 U.S. at 756, but the Supreme Court of Arkansas reversed the conviction, 
a warrantless search of a suitcase in an automobile. In an earlier decision, United States v. Chadwick, ${ }^{65}$ the Court had concluded that police with probable cause to search luggage must obtain a warrant before searching it. ${ }^{66}$ In Sanders, the Court sought to reconcile Chadwick's warrant requirement for luggage with the automobile exception. The Court had to decide whether the presence of luggage in a vehicle nullifies the protection of the warrant requirement that the luggage would otherwise enjoy.

Although recognizing that luggage in an automobile is "as mobile as the vehicle in which it rides," 67 the Court concluded that the automobile exception did not allow a warrantless luggage search for two reasons. ${ }^{68}$ First, the Court found that people have greater expectations of

holding that the warrantless search violated the fourth amendment. Id. The Supreme Court affirmed. Id. at 766 .

65433 U.S. 1 (1977).

66 In Chadwick, federal agents had probable cause to believe that defendants' footlocker contained evidence of a crime. After the defendants placed the footlocker in the trunk of a car, the agents arrested them and seized the footlocker. The agents conducted a warrantless search of the footlocker an hour and a half later, and discovered that it contained marihuana. Id. at 4-5. Because the agents had probable cause to believe that the footlocker, not the vehicle, contained evidence, Chadwick was not an automobile-exception case. The government, therefore, did not contend that the automobile exception validated the search; rather it argued that the reasons for allowing warrantless searches of vehicles also apply to warrantless searches of containers. Id. at 11-12. The Court disagreed, holding that, absent exigent circumstances, police must obtain a warrant to search luggage. Id. at 13,15-16. It refused to accept the government's analogy between vehicles and luggage for two reasons. First, the Court asserted:

The factors which diminish the privacy aspects of an automobile do not apply to [luggage]. Luggage contents are not open to public view . . . nor is luggage subject to regular inspections and official scrutiny on a continuing basis. Unlike an automobile, whose primary function is transportation, luggage is intended as a repository of personal effects. In sum, a person's expectations of privacy in personal luggage are substantially greater than in an automobile.

Id. at 13. Second, storing a vehicle pending issuance of a warrant is more difficult than storing luggage. See id. n.7.

Before and after Chadwick, lower federal courts disagreed on whether the automobile exception authorized warrantless searches of containers located in vehicles. Compare United States v. Johnson, 588 F.2d 147, 152 \& n.6, 153 (5th Cir. 1979) (authorization to search airplane did not extend to duffle bag) and United States v. Stevie, 582 F.2d 1176, 1180 (8th Cir. 1978), cert. denied, 443 U.S. 911 (1979) (luggage search unconstitutional) with United States v. Milhollan, 599 F.2d 518, 527 (3d Cir.), cert. denied, 444 U.S. 909 (1979) (Chambers authorized search of satchel in vehicle); United States v. Tramunti, 513 F.2d 1087, 1103-05 (2d Cir.), cert. denied, 423 U.S. 832 (1975); United States v. Issod, 508 F.2d 990, 993 (7th Cir. 1974), cert. denied, 421 U.S. 916 (1975) (warrantless search of trunks in stationary vehicle constitutional) and United States v. Soriano, 497 F.2d 147, 150 (5th Cir. 1974) (search of luggage in trunk of taxicab constitutional).

67442 U.S. at 763.

68 Chief Justice Burger, joined by Justice Stevens, argued that Sanders was not an automobile-exception case. In Sanders, as in Chadwick, see supra note 66, police had probable cause to search luggage in an automobile, but did not have probable cause to search the automobile itself. Thus " $[\mathrm{t}]$ he relationship between the automobile and the contraband was purely coincidental." Id. at 767 (Burger, C.J., concurring). A majority of the Court adopted Chief Jus- 
privacy in luggage than in automobiles ${ }^{69}$ and stressed that this greater expectation is not diminished by the presence of luggage in an automobile. ${ }^{70}$ Consequently, the Court indicated that police could conduct warrantless searches of containers in vehicles only when "their contents can be inferred from their outward appearance," for such containers "by their very nature cannot support any reasonable expectation of privacy." 71

Second, the Court considered "[t]he difficulties in seizing and securing automobiles" pending issuance of a warrant to be greater than the difficulties involved in seizing and securing containers. ${ }^{72}$ The Court predicated its willingness to allow immediate warrantless searches of vehicles upon its refusal to impose a constitutional requirement that law enforcement agencies seize and hold vehicles until police obtain a warrant. $^{73}$ Because "[n]o comparable burdens are likely to exist with respect to the seizure of personal luggage," the Court was willing to impose a warrant requirement upon police conducting luggage searches. ${ }^{74}$ The Court suggested, however, that it would allow a warrantless luggage search based upon probable cause alone if a threat existed that someone would move the container before police could obtain a warrant. ${ }^{75}$

The reasoning of the Court in Sanders was identical to that in Chadwick. ${ }^{76}$ By refusing to expand the scope of the automobile exception when its rationales did not apply, the Sanders Court indicated that mere presence in a vehicle did not dilute the fourth amendment protection accorded to luggage; police would need a warrant before conducting a search.

Robbins v. Califormia ${ }^{77}$ presented the Court with a difficult variation of the situation in Sanders. In Robbins, police officers had probable cause to believe that the defendant's vehicle, but not any particular container within the vehicle, contained marihuana. ${ }^{78}$ Upon searching the vehicle, the officers discovered two oblong packages, wrapped in opaque plastic, in a recessed luggage compartment. The officers opened the packages

tice Burger's interpretation of Sanders in United States v. Ross, 102 S. Ct. 2157, 2166-67 (1982).

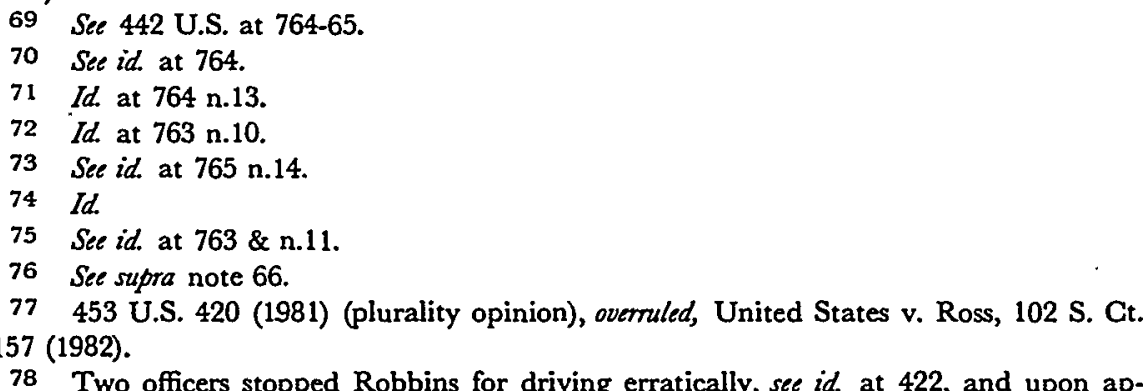
proaching his station wagon, smelled marihuana. 
and discovered two bricks of marihuana. ${ }^{79}$ The trial court admitted the marihuana to convict Robbins. ${ }^{80}$

Four members of the Supreme Court ${ }^{81}$ held that the Sanders rule, proscribing warrantless searches of luggage in vehicles, ${ }^{82}$ applied to the less substantial containers in Robbins ${ }^{83}$ and to all containers that do not reveal their contents. ${ }^{84}$ The plurality refused to adopt a rule affording greater protection to "worthy" containers for two reasons. First, a distinction between luggage and less substantial containers "has no basis in the language or meaning of the Fourth Amendment." 85 Second, "it is difficult if not impossible to perceive any objective criteria by which" police officers and courts could distinguish between various types of containers. ${ }^{86}$ Thus, the plurality rule required police to obtain a warrant to search all closed containers located in vehicles even if the police could conduct a warrantless search of the vehicle under the automobile exception.

In separate dissenting opinions, Justices Blackmun, Rehnquist, and Stevens also refused to distinguish between various types of containers. The dissenters, however, argued for a rule that would extend the automobile exception to all containers in vehicles. ${ }^{87}$

79 Id.

80 After the California appellate court affirmed the conviction, the Supreme Court remanded the case for reconsideration in light of Sanders. Robbins v. California, 443 U.S. 903 (1979). On remand, the state court held that Sanders made unlawful the search of a briefcase and tote bag in Robbins's car, but concluded that Sanders did not make the scarch of the opaque containers unconstitutional. See People v. Robbins, 103 Cal. App. 3d 34, 39, 162 Cal. Rptr. 780, 782 (1980), rev'd, 453 U.S. 420 (1981).

81 Justice Stewart wrote the plurality opinion, in which Justices Brennan, White, and Marshall joined. 453 U.S. at 422 . Chief Justice Burger concurred in the judgment without an opinion. Id. at 429 . Justice Powell concurred in the judgment. Id.

82 See supra notes $64-76$ and accompanying text.

83 See 453 U.S. at 428.

84 The Robbins plurality would have allowed a warrantless search of a container if it "clearly announce[d] its contents, whether by its distinctive configuration, its transparency, or otherwise." Id.; see also Arkansas v. Sanders, 442 U.S. 753, 764 n.13 (1979), limited on other grounds, United States v. Ross, 102 S. Ct. 2157 (1982). Federal courts of appeals have held that various circumstances can reveal a container's contents. See, e.g., United States v. Marshall, 672 F.2d 425, 426 (5th Cir. 1982) (per curiam) (environment of container); United States v. Haley, 669 F.2d 201, 203-04 (4th Cir.) (odor), cert. denied, 102 S. Ct. 2928 (1982). Although the plurality did not consider this exception to the rule proscribing warrantless container searches applicable to the packages in Robbins, see 453 U.S. at 428, Justice Rehnquist disagreed. See id. at 442 (Rehnquist, J., dissenting) (scarch fell "squarely within" exception).

85453 U.S. at 426.

86 Id.

87 See id. at 436 (Blackmun, J., dissenting), 437 (Rehnquist, J., dissenting), 444 (Stevens, J., dissenting). Justice Rehnquist also objected to the application of the exclusionary rule to the states and to the warrant requirement. See id. at 437. Justice Stevens maintained that the scope of a warrantless vehicle scarch should be as broad as the scarch that a magistrate could authorize in a search warrant, and that a magistrate's warrant to search an automobile could authorize a search of the packages in the automobile. See id. at 449 \& n.8. The Court later 
Only Justice Powell, who concurred in the plurality's judgment, would have refused to treat all containers similarly. He would have extended warrant protection only to those containers that "generally [serve] as a repository for personal effects or . . . [have] been sealed in a manner manifesting a reasonable expectation that the contents will not be open to public scrutiny." 88 Justice Powell considered the packages in Robbins to be within his definition of protected containers. ${ }^{89}$

\section{Summary}

At the end of the 1980 Term, the Burger Court clearly would apply the automobile exception to authorize warrantless vehicle searches whenever police had probable cause to search a vehicle. The exigency requirement of Carroll had disappeared. The scope of the automobile exception was less clear. Four Justices refused to extend the exception to containers located in vehicles if the containers did not reveal their contents. ${ }^{90}$ One other, Justice Powell, would have reached the same result only if the containers normally served as repositories for personal effects .or were sealed in a manner manifesting a reasonable expectation that their contents would remain private. 91 Three other Justices would subject all containers located in vehicles to warrantless automobile-exception searches. ${ }^{92}$

\section{B. The Search-Incident-to-Arrest Exception}

The search-incident-to-arrest exception, another judicially created exception to the warrant requirement, authorizes warrantless searches incident to lawful arrests. ${ }^{93}$ Police do not need probable cause to search in order to conduct such searches. Adhering to the dicta of early decisions, ${ }^{94}$ the Supreme Court once allowed police to search the entire

adopted Justice Stevens's approach in United States v. Ross, 102 S. Ct. 2157 (1982). Sec infra notes 114-37.

88453 U.S. at 432 . Concluding that they should adopt as the existing rule the "narrowest grounds" for the Robbins decision, lower courts adopted Justice Powell's concurring position when applying Robbins, because if Powell's test would invalidate a warrantless search, a majority of the Supreme Court would also invalidate the search. See United States v. Martino, 664 F.2d 860, 872-83 (2d Cir. 1981); United States v. Pillo, 522 F. Supp. 855, 866-67 (M.D. Pa. 1981).

89 See 453 U.S. at 429.

90 See supra notes $81-86$ and accompanying text.

91 See supra note 88 and accompanying text.

92 See supra note 87 and accompanying text.

93 See, e.g., Chimel v. California, 395 U.S. 752, 768 (1969). An arrest is lawful when the arresting officer has probable cause to believe that the arrestee committed a crime.

94 E.g., Agnello v. United States, 269 U.S. 20, 30 (1925) (dictum) ("The right without a search warrant contemporancously to search persons lawfully arrested while committing crime and to search the place where the arrest is made in order to find and seize things connected with the crime . . . is not to be doubted."); Carroll v. United States, 267 U.S. 132, 158 (1925) (dictum) ("When a man is legally arrested for an offense, whatever is found upon his person or in his control which it is unlawful to have and which may be used to prove the 
premises of a residence after arresting a person located there, ${ }^{95}$ as long as the intensity of the search was consistent with the nature of the objects that police sought. ${ }^{96}$ Courts frequently relied on this exception to uphold warrantless vehicle searches. ${ }^{97}$ But in Chimel v. California, ${ }^{98}$ the Warren Court limited the scope of the search-incident-to-arrest exception to that necessitated by exigency. Since then, the development of this exception has paralleled that of the automobile exception-the Burger Court has departed from an exigency-based approach.

In Chimel, which involved a warrantless search of an arrestee's home, the Warren Court limited the scope of a warrantless search incident to arrest to "the arrestee's person and the area 'within his immediate control." "99 The Court concluded that a law enforcement officer's need to deny the arrestee access to a weapon or evidence justified a warrantless search. The Chimel Court refused to condone warrantless searches of areas beyond the arrestee's immediate control because it would not be necessary for the protection of police or evidence. ${ }^{100}$ Thus,

offense may be seized and held as evidence in the prosecution."); Weeks v. United States, 232 U.S. 383, 392 (1914) (dictum).

95 See United States v. Rabinowitz, 339 U.S. 56 (1950); Harris v. United States, 331 U.S. 145 (1947). In Agnello v. United States, 269 U.S. 20, 30, 31 (1925), the Court held unconstitutional a search of an arrestee's home following an off-premises arrest. See generally LaFave, Warrantless Searches and the Supreme Court: Further Ventures Into the "Quagmire," 8 CRIM. L. BuLL. 9 (1972).

96 "The same meticulous investigation which would be appropriate in a search for two small cancelled checks could not be considered reasonable where agents are seeking a stolen automobile or an illegal still." Harris v. United States, 331 U.S. 145, 152 (1947). The Supreme Court overruled or distingnished earlier dccisions which gave the search-incident-toarrest exception a narrower construction. United States v. Rabinowitz, 339 U.S. 56, 66 (1950), overruled Trumpiano v. United States, 334 U.S. 699 (1948). Harris v. United States, 331 U.S. 145, 153 (1947) distinguished United States v. Leftkowitz, 285 U.S. 452 (1932) and Go-Bart Importing Co. v. United States, 282 U.S. 344 (1931).

97 See, e.g., Lee v. United States, 376 F.2d 98 (9th Cir.) (warrantless vehicle search upheld as incident to a lawful warrantless arrest), cert. denied, 389 U.S. 837 (1967); Harris v. Stephens, 361 F.2d 888, 893 (8th Cir. 1966) (defendant arrested at front door, warrantless search of automotible in driveway authorized), cert. denied, 386 U.S. 964 (1967); Jackson v. Unitcd States, 352 F.2d 490, 490 (5th Cir. 1965) (warrantless vehicle search authorized as incident to arrest), cert. denied, 385 U.S. 825 (1966). The Supreme Court upheld warrantless vehicle searches in Scher v. United States, 305 U.S. 251, 254-55 (1938) (automobile in garage) and Unitcd States v. Lee, 274 U.S. 559, 563 (1927) (boat), but did not specify whether it relied on Carroll or the search-incident-to-arrest exception. In Preston v. United States, 376 U.S. 364, 367 (1964), the Court held that the search-incident-to-arrest exception did not apply to a warrantless search of a vehicle "remote in time or place from the arrest."

98395 U.S. 752 (1969). Police arrested Chimel at his home for burglary. They had a warrant for his arrest, but lacked a search warrant; nevertheless, they searched the entire house and obtained evidence that the trial court later admitted. Id. at 753-54. The Supreme Court reversed the conviction. See id. at 768.

99 Id. at 763. The Court cited with approval Preston v. United States, 376 U.S. 364 (1964) (proscribing a search-incident-to-arrest "remote in time or place from the arrest").

100 See 395 U.S. at 763 . The dissent argues that although evidence of the burglary was not within the "immediate control" of the arrestee, his wife could have destroyed the evidence while police sought a search warrant. See id. at 775 (White, J., dissenting). 
Chimel is analogous to Carroll: Carroll required exigent circumstances to validate a warrantless automobile search, ${ }^{101}$ and Chimel employs exigency to define the scope of a warrantless search incident to a lawful arrest. According to such an exigency-based approach, a search incident to arrest may encompass the person of the arrestee, ${ }^{102}$ as well as the area ${ }^{103}$ and any containers ${ }^{104}$ within his immediate control.

Although the Burger Court has only recently applied the searchincident-to-arrest exception to uphold a conviction based on evidence obtained in a warrantless vehicle search, ${ }^{105}$ its decision in United States $v$. Robinson ${ }^{106}$ indicated that it would construe broadly the exception in the context of vehicle-related arrests. In Robinson, the Court held that the exception authorizes police who have made custodial arrests ${ }^{107}$ for traffic violations to search the arrestee's person without a warrant. ${ }^{108} \mathrm{Ap}-$ parently following Chimel, the majority in Robinson upheld such a search as necessary to protect the safety of the arresting officer. ${ }^{109}$

The Robinson majority, however, may have actually exceeded the limits set in Chimel by validating a warrantless search of a cigarette package removed from the arrestee's pocket. ${ }^{110}$ The dissent pointed out that once the officer took the package, the arrestee could no longer gain access to it. ${ }^{111}$ Because the package was not within the arrestee's immediate control, Chimel did not authorize a warrantless search. ${ }^{112}$ Thus, the majority in Robinson betrayed a willingness to apply the search-incident-to-arrest exception to a vehicle-related search despite the absence

101 See supra notes 22-29 and accompanying text.

102 See, e.g, Gustafson v. Florida, 414 U.S. 260 (1973); United States v. Robinson, 414 U.S. 218 (1973).

103 See, e.g., Chimel v. California, 395 U.S. 752, 768 (1969).

104 See, e.g., New York v. Belton, 453 U.S. 454, 460 (1981).

105 See New York v. Belton, 453 U.S. 454 (1981). For a discussion of Belion, see infra notes 144-58 and accompanying text.

106414 U.S. 218 (1973). After arresting Robinson for driving with a revoked license, a police officer conducted a routine search of his person and discovered a crumpled cigarette package in his jacket pocket. The officer opened the package and discovered heroin inside. The trial court admitted this evidence to convict Robinson. Id. at 220-23.

107 When a police officer conducts a "custodial arrest," he takes custody of the arrestee. See infra note 161 .

108 See 414 U.S. at 224.

109 Both Robinson and Gustafson v. Florida, 414 U.S. 260 (1973), a case with facts and outcome similar to Robinson, differed from other cases involving searches incident to arrest because they did not involve a threat that the arrestees would destroy evidence. The Robinson Court recognized that there would be no tangible evidence of traffic violations and no need to conduct a warrantless search to protect evidence. Thus, only protection of the arresting officers justified the Robinson and Guslafson searches. See Robinson, 414 U.S. at 234. For a discussion of searches incident to arrests for traffic violations, see LaFave, supra note 11, at 150-61; infra note 239 and accompanying text.

110 In neither Robinson nor Gustafson did the majority distinguish between a search of the person of the arrestee and a search of a container found on his person.

111 See 414 U.S. at 255-56 (Marshall, J., dissenting).

112 Id. 
of the exigent circumstances that justify the exception. ${ }^{113}$

\section{Ross and Belton: Recent Developments in the Burger Court's Vehicle Jurisprudence}

\section{The Automobile Exception: United States v. Ross}

United States 0. Ross ${ }^{114}$ provided the Supreme Court with the opportunity to reconsider the Robbins rule, which required warrants for searches of containers in vehicles. ${ }^{115}$ In Ross, District of Columbia police officers stopped Ross's car after receiving an informant's tip that Ross was selling narcotics. ${ }^{116}$ After noticing a bullet on the front seat and finding a gun in the glove compartment, one of the officers used Ross's key to open the car's trunk, where he found a closed paper bag. The officer opened the bag to discover "a number of glassine bags containing white powder" that was later determined to be heroin. ${ }^{117}$ At no time did the police obtain a warrant to search the bag. ${ }^{118}$ Denying a motion to suppress, the trial court admitted the heroin to convict Ross. ${ }^{19}$ The court of appeals, however, concluded that the search of the paper bag violated the fourth amendment. ${ }^{120}$ The Supreme Court granted certiorari to reconsider Robbins ${ }^{121}$ and reversed. ${ }^{122}$

Justice Stevens, writing for a six-member majority, extended the scope of the automobile exception to all containers inside vehicles:

113 Robinson also expands police power to conduct warrantless searches incident to arrests by allowing police to conduct such searches whether or not they believe that an arrestee may gain access to weapons or evidence. Thus, even if an arresting officer does not believe that a search is necessary to protect himself or evidence, he still has the "general authority" to conduct the search. Id. at 234; see also LaFave, supra note 11.

114102 S. Ct. 2157 (1982). For a discussion of Ross, see generally 2 LAFAVE, supra note 16, at 169-77 (Supp. 1983); Latzer, Searching Cars and Their Conlents: United States v. Ross, 18 CRIM. L. Bull. 381 (1982); The Supreme Court, 1981 Term-Search and Seizure, 96 HaRv. L. REV. 62, 176 (1982); 66 MARQ. L. REV. 161 (1982).

115 The Court granted certiorari in Ross to determine whether to reconsider Robbins. 454 U.S. 891 (1981).

116 A previously reliable informant notified police officers that Ross was selling narcotics from the trunk of his car, and told them where the car was parked. The officers drove to the location, found the car unoccupied, confirmed that the car was registered to Ross, and left the area to avoid arousing suspicion. They returned five minutes later to see Ross driving the car away and proceeded to stop the car. $102 \mathrm{~S}$. Ct. at 2160.

117 Id. A subsequent warrantless search of the trunk of the ear at the police station uncovered a zippered red leather pouch containing $\$ 3,200$. Id.

118 Id.

119 The trial court also admitted money that police found in a zippered leather pouch. Id.

120 See United States v. Ross, 655 F.2d 1159, 1161 (D.C. Cir. 1981) (en banc), rev'd, 102 S. Ct. 2157 (1982). Before the en banc hearing, a three-judge panel of the court of appeals held that the search of the paper bag was constitutional, but reversed the conviction on other grounds. United States v. Ross, No. 79-1624 (D.D.C. Apr. 17, 1980) (search of zippered pouch violated Sanders and therefore trial court erred by admitting money).

121 See 454 U.S. 891 (1981).

122 See United States v. Ross, 102 S. Ct. 2157, 2173 (1982). 
We hold that the scope of the warrantless search authorized by [the automobile] exception is no broader and no narrower than a magistrate could legitimately authorize by warrant. If probable cause justifies the search of a lawfully stopped vehicle, it justifies the search of every part of the vehicle and its contents that may conceal the object of the search. ${ }^{123}$

The Court's explanation for this broad rule revealed a marked departure from the rationales of earlier decisions. ${ }^{124}$ Perhaps aware that neither the old "exigency" rationale nor the more recent "diminished privacy expectations" and "administrative burdens" rationales for the automobile exception would support its broad rule, ${ }^{125}$ the Court turned elsewhere for support.

First, the Court contended that the prior automobile-exception cases authorized police to conduct warrantless searches of containers located in vehicles if they had probable cause to believe that the vehicle contained evidence of a crime. ${ }^{126}$ Dismissing Robbins ${ }^{127}$ and distinguishing Sanders, ${ }^{128}$ the Court relied on Carroll, in which police found contraband in a car's upholstery, and Chambers, in which the evidence was located in a concealed compartment. ${ }^{129}$ The Court also relied on two pre-Chambers opinions that upheld warrantless searches of containers in vehicles when police had probable cause to search the vehicles. ${ }^{130}$

Second, the Court stressed the needs of law enforcement officials. Concluding that criminals will almost always carry contraband in containers, the Court reasoned "that the practical consequences of the Carroll decision would be largely nullified if the permissible scope of a

\section{Id. at 2172.}

124 Despite this departure, the result in Ross was foreseeable. After Justice Stewart's retirement, only three members of the Robbins plurality remained on the Court: Justices Brennan, Marshall, and White. The same number of Justices-Blackmun, Rehnquist, and Stevens-had dissented, advocating the extension of the automobile exception to all containers in vehicles. See supra note 87 and accompanying text. Justice Powell had indicated that he might adopt the dissenters' approach in a future case. See Robbins v. California, 453 U.S. 420,435 (1981) (Powell, J., concurring). Thus, with Justice Powell's vote, either Chief Justice Burger's or Justice O'Conner's vote would have sufficed to establish the Ross rule.

125 See supra notes 67-76 and accompanying text.

126 See 102 S. Ct. at 2169-70.

127 See id. at 2172 ("'A]lthough we reject the precise holding in Robbins, there was no Court opinion supporting a single rationale for its judgment and the reasoning we adopt today was not presented by the parties in that case.").

128 "Although we have rejected some of the reasoning in Sanders, we adhere to our holding in that ease [that police with probable cause to search luggage in a vehicle, and without probable cause to search the entire vehicle, must obtain a warrant to search the luggage.]" Id. Although this may be a valid interpretation of the strict holding of Sanders, see supra note 68, the Sanders Court actually articulated a rule inconsistent with Ross: that police with probable cause to seareh a vehicle need a warrant to search luggage in the vehicle. See supra notes 64-75 and accompanying text.

129 See 102 S. Ct. at 2169. See generally supra notes 22-28, 37-44 and accompanying text. 130 See $102 \mathrm{~S}$. Ct. at 2169 . For a discussion of the Court's use of authority, see supra note 29; infra notes $189-96$ and accompanying text. 
warrantless search of an automobile did not include containers and packages found inside the vehicle." ${ }^{\prime 31}$ Thus, the Court assumed a need for a robust automobile exception and extended the exception's scope to satisfy this need.

The Court also concluded that a warrant requirement for containers in vehicles would compel police to seize and hold vehicles until they could obtain a warrant to search the containers. Otherwise, "police could never be certain that the contraband was not secreted in a yet undiscovered portion of the vehicle."132 This, in turn, would make the automobile exception unnecessary, for if police must hold a vehicle pending issuance of a warrant to search containers in the vehicle, they could also seek a warrant to search the vehicle itself. ${ }^{133}$

Finally, the Court turned to the privacy interests of vehicle owners and occupants. It concluded that a rule allowing warrantless searches of vehicles, while disallowing such searches of containers in the vehicles, would lead to intrusions on privacy: "[P]rohibiting police from opening immediately a container in which the object of the search is most likely to be found and instead forcing them first to comb the entire vehicle would actually exacerbate the intrusion on privacy interests. . . ."134

The Ross Court placed two limits on the scope of its expanded automobile exception. First, by adhering to its "holding" in Sanders, ${ }^{135}$ the Court continues to proscribe warrantless searches of containers in vehicles when probable cause to search focuses on the container specifically, and not on the vehicle generally. ${ }^{136}$ Second, the Court requires that the nature of the objects sought delimit the scope and intensity of warrantless vehicle searches. ${ }^{137}$

Justices Blackmun and Powell joined the majority opinion and judgment. Their concurring opinions, however, suggest that their desire

\section{$131102 \mathrm{~S}$. Ct. at 2170.}

132 Id. at 2171 n.28.

133 This rationale is implicit in the Ross Court's discussion of the "practical considerations that justify a warrantless search . . . . Id. The Court concludes that a requirement that police hold vehicles while seeking warrants to search containers "would be directly inconsistent with the rationale supporting the decisions in Carroll and Chambers." Id.

134 Id.

135 See supra note 128.

136 See 102 S. Ct. at 2179 (Marshall, J., dissenting). Justice Marshall doubted whether this limitation would be practically significant: "In practice, the Court's rule may amount to a wholesale authorization for police to search any ear from top to bottom when they have suspicion, whether localized or general, that it contains contraband." Id. at 2182 n.14 (Marshall, J., dissenting).

137 Just as probable cause to believe that a stolen lawnmower may be found in a garage will not support a warrant to search an upstairs bedroom, probable cause to believe that undocumented aliens are being transportcd in a van will not justify a warrantless search of a suitcase. Probable cause to believe that a container placed in the trunk of a taxi contains contraband or evidence does not justify a search of the entire cab.

Id. at 2172. 
for "an authoritative ruling" 138 and "a readily understood and applied rule," 139 rather than agreement with the majority's reasoning, prompted them to join the majority.

In a well-argued dissent, Justice Marshall accused the majority of adopting "an unprecedented 'probable cause' exception to the warrant requirement." 140 Justice Marshall contended that neither the "diminished privacy expectations" nor "administrative burdens" rationales justified the broad scope of the majority's automobile exception, ${ }^{141}$ and that the majority's alternative rationales failed to support its position. ${ }^{142}$ Furthermore, he considered illogical the majority's decision to equate the scope of an automobile-exception search with the scope of a search that a magistrate could authorize. ${ }^{143}$

\section{The Search-Incident-to-Arrest Exception: New York v. Belton}

In New York v. Belton, ${ }^{144}$ the Court expanded the scope of the search-incident-to-arrest exception in a vehicle-search case. In Belton, a state trooper arrested the occupants of a speeding car for possession of marihuana. ${ }^{145}$ The trooper searched the car's passenger compartment where he found a jacket belonging to Belton. The trooper found cocaine in a pocket of the jacket. ${ }^{146}$ After a trial court denied his motion to suppress the evidence, Belton pleaded guilty. ${ }^{147}$ The New York Court of

138 Id. at 2173 (Blackmun, J., concurring).

139 Id. (Powell, J., concurring).

140 Id. at 2174 (Marshall, J., dissenting). Justice Brennan joined Justice Marshall's dissent. Justice White wrote a separate dissenting opinion. See id. at 2173 (White, J., dissenting).

141 Id. at 2176 (Marshall, J., dissenting).

142 Id. at 2179.

143 The majority's sleight-of-hand ignores the obvious differences between the function served by a magistrate in making a determination of probable cause and the function of the automobile exception. [Although relevant to the automobile exception, it] is irrelevant to a magistrate's function whether the items subjcct to search are mobile, may be in danger of destruction, or are impractical to store, or whether an immediate scarch would be less intrusive than a seizure without a warrant. A magistrate's only conceru is whether there is a probable cause to search them . . . . Because thc scope of a warrantless search should depend on the scope of the justification for dispensing with a warrant, the entire prcmise of the majority's opinion fails to support its conclusion.

Id. at 2177 (emphasis in original).

144453 U.S. 454 (1981). For a discussion of Belton, see generally 2 LAFAVE, supra note 16, at 152-60 (Supp. 1983); Note, Arrestee's Scope of Immediate Control: An Expansive Definition, 28 LoY. L. REv. 359 (1982); 47 Mo. L. REv. 545 (1982); 9 Ohio N.U.L. REV. 153 (1982); 9 Pepperdine L. Rev. 919 (1982).

145 After stopping the car for speeding and asking to see respondent's driver's license and automobile registration, the trooper "smclled burnt marihuana and [saw] on the floor of the car an envelope marked 'Supergold' that he associated with marihuana." Id. at 455-56. The Court assumed that the subsequent arrest was lawful. See id. at 456-57.

146 Id. at 456.

147 Id. 
Appeals reversed the conviction, ${ }^{148}$ holding the search-incident-to-arrest exception inapplicable because the arrestees were unable to gain access to the jacket at the time of the search. The Supreme Court granted certiorari ${ }^{149}$ and reversed, upholding the conviction. ${ }^{150}$

Five members of the Court ${ }^{151}$ held that the search-incident-to-arrest exception authorizes police who have arrested the occupant of a vehicle to search, without a warrant, the vehicle's passenger compartment and any containers therein. ${ }^{152}$ The Court purported to follow Chimel's "immediate control" test, ${ }^{153}$ yet did not consider whether the arrestees could have gained access to the jacket's contents. ${ }^{154}$ Instead, it adopted a "straightforward rule, easily applied and predictably enforced": ${ }^{155}$ An officer conducting a custodial arrest of a vehicle's occupant may conduct a warrantless search of the passenger compartment of the vehicle and any containers located there. ${ }^{156}$ The Court defended this rule by asserting "that articles inside the relatively narrow compass of the passenger compartment of an automobile are in fact generally, even if not inevitably, within" an arrestee's immediate control. ${ }^{157} \mathrm{De}$ spite this assertion, Belton authorizes warrantless passenger compartment searches in the nonexigent circumstances in which evidence or weapons in a vehicle's passenger compartment are beyond an arrestee's immediate control. ${ }^{158}$

148 People v. Belton, 50 N.Y.2d 447, 452, 407 N.E.2d 420, 423, 429 N.Y.S.2d 574, 577 (1980), rev'd, 453 U.S. 454 (1981).

149 See 449 U.S. 1109 (1980).

150 See 453 U.S. at 463.

151 Justice Stewart, joined by Chief Justice Burger and Justices Blackmun, Powell, and Rehnquist, wrote the majority opinion. Although Justice Rehnquist joined the majority opinion, he preferred that the Court either not apply the exclusionary rule to the states or apply the "automobile exception" to allow the search. Id. at 463 (Rehnquist, J., concurring).

152 See id. at 460.

153 See id. at 460 n.3.

154 The arrestees outnumbered the trooper four-to-one and were standing outside of the car when the trooper searched the passenger compartment and jacket. Brief for Petitioner at 3, New York v. Belton, 453 U.S. 454 (1981). The trooper did not handcuff any of the arrestees. Id. He stated that he never felt threatened and did not draw his service revolver during the arrest and search. Brief for Respondent at 12, New York v. Belton, 453 U.S. 454 (1981).

155453 U.S. at 459.

156 Id. at 460.

[W]e hold that when a policeman has made a lawful custodial arrest of the oceupant of an automobile, he may, as a contemporaneous incident of that arrest, search the passenger compartment of that automobile.

It follows from this conclusion that the police may also examine the contents of any containers found within the passenger compartment, for if the passenger compartment is within reach of the arrestee, so also will containers in it be within his reach.

Id. (footnotes omitted).

157 See id.

158 With the retirement of Justice Stewart, only four members of the Belion majority remain on the Court. See supra note 151. At least one of them, Justice Rehnquist, preferred to 
Justice Stevens concurred in the judgment, ${ }^{159}$ but considered the majority's rule a "massive broadening" of the search-incident-to-arrest exception. ${ }^{160} \mathrm{He}$ feared that the rule would allow police to conduct "unreasonable searches" after every arrest, including arrests for traffic violations. ${ }^{161}$ He preferred that the Court instead apply a broad automobile exception. ${ }^{162}$

In dissent, Justice Brennan criticized the majority approach as "analytically unsound" and inconsistent with earlier search-incident-to-arrest decisions. ${ }^{163} \mathrm{He}$ maintained that the majority ignored Chimel "and instead adopt[ed] a fiction-that the interior of a car is always within the immediate control of an arrestee who has recently been in the car."164 In a short dissent, Justice White described the majority approach as "an extreme extension of Chimel." 165

\section{Summary}

After Ross and Belton, the automobile exeeption authorizes police who have probable cause to believe that a vehicle contains evidence of a crime to conduct a warrantless search of the entire vehicle ${ }^{166}$ and any containers in it. ${ }^{167}$ The police may conduct the search immediately at the scene of the stop, or later, after seizing the vehicle and taking it to the police station. ${ }^{168}$ Furthermore, if a police officer lawfully arrests a vehicle's occupant, the search-incident-to-arrest exception authorizes the

decide the case under the automobile exception, which he believed should allow the warrantless search. See supra note 151. Because the Ross Court extended the automobile exception to authorize warrantless container searches like that in Bellon, Justice Rehnquist may now be less likely to embrace the Belion rule. Although it is doubtful that the Court will overrule Belion, expansion of the Belton rule appears unlikely and unnecessary after Ross.

159 The substance of Justice Stevens's concurring opinion appears in his dissent in Robbins v. California, 453 U.S. 420, 444 (1981) (Stevens, J., dissenting), overnuled, United States v. Ross, 102 S. Ct. 2157 (1982).

160 See 453 U.S. at 452 (Stevens, J., dissenting). Although Justice Stevens referred to a "massive broadening of the automobile exception," his opinion makes clear that he is concerned with the Court's treatment of the search-incident-to-arrest exception.

161 See id. at $451 \mathrm{n} .12$. Justice Stevens maintained that the majority's approach would allow police officers to search any vehicle, or any containers in vehicles, without probable cause to search if the search was incident to a "custodial arrest," an arrest in which the officer takes custody of the arrestee. Noting an absence of constitutional restraints on a police officer's ability to make custodial arrests, see id. at $450 \mathrm{n} .11$, Justiee Stevens argued that the Bellon approach potentially could apply to every arrest. He did, however, recognize that there are state constitutional restraints on custodial arrests for traffic violations. Id. n.12. See also infra notes $237-39$ and accompanying text.

162 See supra note 87 and accompanying text. The Court later adopted Justice Stevens's proposed automobile exception in Ross. See supra text accompanying note 123.

163 See 453 U.S. at 468 (Brennan, J., dissenting).

164 Id. at 466 (emphasis in original).

165 Id. at 472 (White, J., dissenting).

166 Sec, e.g., Texas v. White, 423 U.S. 67 (1975) (per curiam).

167 See United States v. Ross, 102 S. Ct. 2157, 2172 (1982).

168 See, e.g., Michigan v. Thomas, 102 S. Ct. 3079 (1982) (per curiam); Chambers v. Maroney, 399 U.S. 42 (1970). 
officer to conduct an immediate warrantless search of the arrestee ${ }^{169}$ and the vehicle's passenger compartment, ${ }^{170}$ as well as any containers on the arrestee's person ${ }^{171}$ or in the passenger compartment. ${ }^{172}$ Although the search-incident-to-arrest exception requires an arrest supported by probable cause to arrest, it does not require that police have probable cause to search. ${ }^{173}$ The search-incident-to-arrest exception does not allow searches "remote in time or place from the arrest."174

\section{II}

\section{The Burger Court's Analysis: An Evaluation and EXPLANATION}

In Ross and Belton, the Burger Court tried to resolve difficult issues raised by warrantless vehicle searches. Both cases reveal a Court struggling to accomplish three objectives: establish understandable and easily-applied rules, ${ }^{175}$ articulate convincing justifications of the rules, and achieve a consensus within the Court. The Court's efforts have yielded limited success. Ultimately, the problems that the Court is struggling to alleviate are the consequences of its own decisions, decisions that sever the automobile and search-incident-to-arrest exceptions from their original justifications—exigency created by a threat to evidence or to police.

\section{A. The Automobile Exception}

\section{Application}

The Burger Court's automobile exception applies whenever police have probable cause to believe that the vehicle to be searched contains evidence of a crime. The Court has articulated three rationales to support this rule: inherent mobility of vehicles, ${ }^{176}$ diminished expectations of privacy in vehicles, ${ }^{177}$ and the administrative burdens of seizing and storing vehicles. ${ }^{178}$ These rationales do not adequately support the broad application of the automobile exception.

169 See, e.g., United States v. Robinson, 414 U.S. 218 (1973).

170 See New York v. Belton, 453 U.S. 454 (1981).

171 See, e.g., United States v. Robinson, 414 U.S. 218 (1973).

172 See New York v. Belton, 453 U.S. 454 (1981).

173 Probable cause to arrest may exist when probable cause to search is absent. See $1 \mathrm{~W}$. LAFAVE, supra note 16, at 441-42. Police making arrests for traffic violations, see, e.g., United States v. Robinson, 414 U.S. 218 (1973), or conducting material witness arrests, see, e.g., United States v. Farinacci-Garcia, 551 F. Supp. 465 (D.P.R. 1982), may have probable cause to arrest but not to search.

174 See, e.g., United States v. Chadwick, 433 U.S. 1, 15 (1977); Preston v. United States, 376 U.S. 364,367 (1964).

175 See United States v. Ross, 102 S. Ct. 2157, 2161-62 (1982); New York v. Belton, 453 U.S. 454, 458-59 (1981).

176 See supra notes 58-59 and accompanying text.

177 See supra notes 53-54 and accompanying text.

178 See supra notes 60-62 and accompanying text. 
a. Inherent Mobility. The Court correctly characterizes vehicles as inherently mobile; yet it does not identify any logical nexus between inherent mobility and an exception to the warrant requirement. When a suspect or arrestee can move a vehicle before a magistrate issues a warrant, circumstances necessitate a warrantless search. When the vehicle is inherently mobile but actually immobile, no reason exists to excuse police from obtaining a warrant. "Inherent mobility" appears to be a catchword for diminished fourth amendment protection, not a substantive rationale for excusing noncompliance with the warrant requirement.

b. Diminished Expectations of Privacy. The Court has asserted that people have lesser expectations of privacy in their automobiles than in other property, and relies upon this assertion to justify warrantless vehicle searches and to distinguish vehicles from containers. The Court's analysis of privacy expectations, however, is flawed. First, the validity of the Court's basic assertion is questionable. ${ }^{179}$ People reasonably expect that the contents of their trunk or glove compartment or objects beneath their seats will remain private. Furthermore, people often use vehicles as residences or as containers for personal effects; ${ }^{180}$ therefore, the Court should not summarily deny vehicles the privacy protection that it accords residences and containers. ${ }^{181}$

Second, the reasons upon which the Court has relied to support its assertion that people have lesser expectations of privacy in vehicles are not convincing. The Court has articulated the following reasons: a vehicle is a means of transportation, not a residence; a vehicle is exposed to public scrutiny; and a vehicle is subject to governmental regulation. ${ }^{182}$ These facts fail to distinguish vehicles from residences and containers. People often use vehicles as residences and places to store personal effects. Vehicles are no less incapable of escaping public scrutiny than are people and personal property carried in public. Furthermore, residences are also subject to governmental regulation, yet receive full fourth amendment protection. ${ }^{183}$ Thus, there are flaws in the reasoning that the Court employs to reach the conclusion that people have lesser expectations of privacy in vehicles.

Finally, assuming that people do have diminished privacy expectations in vehicles, that alone does not justify warrantless vehicle searches. The warrant requirement ensures that a neutral and detached magis-

179 See Wilson, supra note 16, at 130; Comment, supra note 14, at 951-53.

180 See Wilson, supra note 16, at 158; Comment, supra note 14, at 957.

181 See e.g., Payton v. New York, 445 U.S. 573 (1980) (search warrant required for search to arrest at residence); United States v. Chadwick, 433 U.S. 1, 12-13 (1977) (warrant required for luggage search).

182 See supra note 54.

183 See, e.g., Payton v. New York, 445 U.S. 573 (1980) (search warrant required for search to arrest at residence). 
trate will assess the reasonableness of a search in order to determine its permissibility. ${ }^{184}$ Lesser privacy expectations in a vehicle, however, will not ensure that a police officer will be detached and neutral when deciding whether to search a vehicle. Regardless of an individual's expectations of privacy in a vehicle, the reasons for the warrant requirement still apply to vehicle searches. ${ }^{185}$

c. Administrative Burdens. The Court has applied the automobile exception as a means of relieving police departments of the burdens of seizing and storing vehicles pending the issuance of search warrants; yet the Court fails to support its assertion that these burdens are "severe, even impossible." 186 Even assuming the validity of the Court's concerns, this rationale suffers from an over-generalization. The Court does not contend that a storage requirement would impose undue burdens on all police departments; indeed, the Court recognizes that some departments have resources and facilities sufficient to store vehicles. ${ }^{187}$ Although administrative burdens may justify warrantless vehicle searches when a police department cannot seize and hold vehicles, these burdens do not support such searches when a police department has sufficient resourceis to seize and hold vehicles while police seek warrants.

The cogency of the administrative-burdens rationale suffers from another weakness: the Court has allowed warrantless vehicle searches conducted after police had seized the vehicle, taken it to the police station, and held it there. ${ }^{188}$ In these instances, the police manifested an ability and a willingness to bear the burdens of seizure and storage. Thus, it is difficult to understand the Court's reliance on these burdens as a reason for allowing warrantless searches.

\section{Scope}

After the Supreme Court had decided that the automobile exception applies whenever police have probable cause to search a vehicle, it

\section{See supra note 15.}

185 The Court may have adopted the unarticulated position that, given the diminished privacy expectations of vehicle users, the administrative burdens of obtaining a search warrant outweigh the diminished privacy interests that the requirement would protect.

186 Arkansas v. Sanders, 442 U.S. 753, 765-66 n.14 (1979), limited on other grounds, United States v. Ross, 102 S. Ct. 2155 (1982); see The Supreme Court, 1981 Term, supra note 114, at 183 ("The . . . concern seems to be based on the dubious fear that some mysterious confederate will sneak into the police parking lot with an extra set of keys and remove evidence and on the further doubtful assumption that present police storage facilities are inadequate.").

187 "Such a constitutional requirement [of seizure and storage of vehicles pending issuance of a warrant] . . . would have imposed severe, even impossible burdens on many police departments." Arkansas v. Sanders, 442 U.S. 753, 765-66 n.14 (1979) (emphasis added), limited on other grounds, United States v. Ross, 102 S. Ct. 2155 (1982). Some vehicles pose more significant storage burdens than do others. See, e.g., United States v. Olson, 670 F.2d 185 (11th Cir. 1982) (airplane search).

188 See, e.g., Texas v. White, 423 U.S. 67 (1975) (per curiam); Chambers v. Maroney, 399 U.S. 42 (1970). 
had to decide the proper scope of an automobile-exception search. In United States v. Ross, the Court concluded that a warrantless automobile exception search extends to the entire vehicle and any containers in it. The Court offered three reasons to justify this extensive scope: previous Supreme Court decisions, perceived needs of law enforcement agencies, and privacy interests. These reasons, however, fail to justify adequately the broad scope of the Burger Court's automobile exception.

a. Previous Decisions. In United States v. Ross, the Court argued that earlier decisions support its conclusion that the automobile exception extends to all compartments and containers in vehicles. ${ }^{189}$ The Court relied on four cases to buttress this argument. None of these cases supports the result in Ross.

First, the Court noted that both Carroll v. United States and Chambers v. Maroney authorized warrantless searches of concealed areas in the vehicles. The Court interprets this as a mandate to extend the automobile exception to all containers and compartments in a vehicle. ${ }^{190}$ By relying on Carroll and Chambers, the Court ignored a fundamental difference between a concealed compartment that is a part of a vehicle and a moveable container that is located in a vehicle: police can more easily seize and hold containers pending issuance of a warrant. Indeed, a majority of the Supreme Court has recoguized this distinction between vehicles and containers. ${ }^{191}$

The Ross Court also invoked Husty v. United States ${ }^{192}$ and Scher $v$. United States, 193 cases in which the Court upheld warrantless automobile searches that extended to containers. ${ }^{194}$ Husty and Scher are only minimally persuasive, however, for as the Court conceded, the parties in those cases did not argue that police needed a warrant to search the containers. ${ }^{195}$

The validity of the Ross Court's reliance upon these cases is suspect

189 See Ross, 102 S. Ct. at 2169.

190 If it was reasonable for prohibition agents to rip open the upholstery in Carroll, it certainly would have been reasonable for them to look into a burlap sack stashed inside; if it was reasonable to open the concealed compartment in Chambers, it would have been equally reasonable to open a paper bag crumpled within it.

Id.

191 See supra notes 72-74 and accompanying text; see also Ross, $102 \mathrm{~S}$. Ct. at 2179 (Marshall, J., dissenting) ("Surely an integral compartment within a car is just as mobile, and presents the same practical problems of safekeeping, as the car itself. This cannot be said of movable containers located within the car.").

192282 U.S. 694 (1931).

193305 U.S. 251 (1938).

$194102 \mathrm{~S}$. Ct. at 2169 .

195 Id. In Ross, the majority and dissent disagreed about the importance of Husty and Scher. The majority contended that "[t]he fact that no such argument was even made illuminates the profession's understanding of the scope of the search permitted under Carroll." Id. In dissent, Justice Marshall labeled this an "unusual approach to constitutional interpretation." Id. at 2178 n.7. 
for another reason. All four cases preceded the Court's privacy-expectations analysis ${ }^{196}$ and were decided when exigency defined the permissible scope of a search. Now that the Court considers an analysis of privacy expectations central to its automobile exception, it should hesitate to rely on decisions predating that analysis. The persuasiveness of these decisions is the weakest when the Court seeks to apply the automobile exception to areas in which people have high expectations of privacy, such as containers and closed compartments in vehicles.

b. Law Enforcement Needs. The Ross Court also extends the automobile exception to containers in vehicles in order to promote more efficient law enforcement. According to the Court, a contrary rule would render the automobile exception impotent because criminals usually enclose contraband in containers, ${ }^{197}$ and unnecessary because police departments that hold vehicles while seeking warrants to search containers in them could also seek warrants to search the vehicles. ${ }^{198}$ Assuming that these assertions are true, they fail to dictate the resulting rule.

By allowing the vitality of the automobile exception to control its scope, the Court exalts police efficiency in the form of a robust automobile exception over both logic and the fourth amendment. If a limited scope of the exception would frequently render the application of the automobile exception useless or unnecessary, perhaps the Court should reconsider the applicability of the exception. Instead, the Court makes the automobile exception an end in itself and expands its scope to insure its usefulness to police.

In short, the Court is apparently unwilling to allow limitations on the scope of the automobile exception, limitations dictated by what the Court admits are differences between vehicles and containers, ${ }^{199}$ to impede extensive vehicle searches:

When a legitimate search is under way, and when its purpose and its limits have been precisely defined, nice distinctions between closets, drawers, and containers, in the case of a home, or between glove compartments, upholstered seats, trunks, and wrapped packages, in the case of a vehicle, must give way to the interest in the prompt and efficient completion of the task at hand. ${ }^{200}$

Thus, the Ross Court, somewhat incredibly, explicitly adopted the position that more efficient law enforcement warrants the curtailment of fourth amendment protection. This directly contradicts the Court's general rule that "the mere fact that law enforcement may be made more efficient can never by itself justify disregard for the Fourth

196 See supra notes 53-54 and accompanying text.

197 See supra note 131 and accompanying text.

198 See supra notes $132-33$ and accompanying text.

199 See supra notes $67-74$ and accompanying text.

200102 S. Ct. at 2170-71. 
Amendment."201

c. Privacy Interests. The Ross Court concluded that a rule allowing police to conduct warrantless searches of containers in vehicles will protect the privacy interests of vehicle users. Police unsure whether contraband is in a container or a "yet undiscovered portion of the vehicle" will be able to search the container instead of "combing" the entire vehicle for evidence. ${ }^{202}$ In dissent, Justice Marshall exposed a flaw in this argument:

The search will not always require a "combing" of the entire vehicle, since police may be looking for a particular item and may discover it promptly. If, instead, they are looking more generally for evidence of a crime, the immediate opening of a container will not protect the defendant's privacy; whether or not it contains contraband, the police will continue to search for new evidence. ${ }^{203}$

In short, the object of the search, not the presence of unopened containers, will usually determine the extent of a warrantless vehicle search. Thus, police may "comb" vehicles for evidence despite the rule in Ross.

Even if the Ross rule would protect privacy interests by limiting thorough police searches, that alone does not justify the broad scope of the Court's automobile exception. If an extensive search would be an undue privacy intrusion, the vehicle-user would consent to an immediate warrantless search of unopened containers to avoid the greater intrusion. ${ }^{204}$ Thus, the Ross rule is not necessary to prevent unwanted intrusions on privacy.

\section{B. The Burger Court's Search for Simplicity}

Although the reasons that the Burger Court has given to support its rules governing warrantless vehicle searches, under both the automobile and search-incident-to-arrest exceptions, are not persuasive, ${ }^{205}$ the exceptions may be justifiable as "bright-line" rules necessary and sufficient to guide lower courts and police. Courts and commentators have recognized the importance of understandable fourth amendment doctrine, doctrine that governs routine police conduct. ${ }^{206}$ This concern is at least

201 Mincey v. Arizona, 437 U.S. 385, 393 (1978) (emphasis added); see also Ross, 102 S. Ct. at 2181 (Marshall, J., dissenting).

202102 S. Ct. at 2171 n.28.

203 Id. at 2179 (Marshall, J., dissenting).

204 Cf. id. at 2179-80 (arguing that user would consent to search to avoid having car impounded).

205 See supra notes 157-58, 176-204 and accompanying text.

206 See, e.g., 102 S. Ct. at 2161 ("There is . . no dispute among judges about the importance of striving for clarification in this area of the law."). Professor LaFave advocates a "standardized procedure" rather than "case-by-case adjudication":

Fourth Amendment doctrine, given force and effect by the exclusionary rule, is primarily intended to regulate the police in their day-to-day aetivities and thus ought to be expressed in terms that are readily applicable by the police 
partially responsible for the Burger Court's automobile and vehicle search-incident-to-arrest exceptions. The Court has attempted to simplify the exceptions by replacing case-by-case analysis with generally applicable rules. The success of the Court's attempt to provide "straightforward rule[s], easily applied, and predictably enforced"207 depends upon whether these rules are necessary to guide police; whether they in fact provide guidance; and whether their benefits exceed their costs, unwarranted privacy intrusions. ${ }^{208}$ Based on these standards, the Court's "bright-line" rules have failed.

\section{The Automobile Exception: Generalized Application Versus an Exigency-Based Approach}

The Burger Court has attempted to simplify the automobile exception by adopting a generalized application of the rationales for the exception or by ignoring the rationales completely. First, the Court assumes that people always have diminished privacy expectations in vehicles without considering their actual expectations. ${ }^{209}$ Second, the Court refuses to require any police departments to seize and hold vehicles pending issuance of a warrant although it recognizes that many could comply with such a requirement. ${ }^{210}$ Third, the Court relies on "inherent mobility," a denominator common to all automobiles, rather than actual mobility, an inquiry that would necessitate a case-by-case approach. ${ }^{211}$ Finally, when faced with containers located in vehicles

\footnotetext{
in the context of the law enforcement activities in which they are necessarily engaged. A highly sophisticated set of rules, qualified by all sorts of ifs, ands, and buts and requiring the drawing of subtle nuances and hairline distinctions, may be the sort of heady stuff upon which the facile minds of lawyers and judges eagerly feed, but they may be "literally impossible of application by the officer in the field."
}

LaFave, supra note 11 , at 141 (footnotes omitted). In his article Professor LaFave considered United States v. Robinson, 414 U.S. 218 (1973), which held that a search incident to arrest of the arrestee's person was neither limited by the probability that the arrestee could reach a weapon, see supra note 113 , nor restricted to the intensity necessary to discover weapons or evidence. LaFave agrees with the majority's rejection of these limitations because they would require case-by-case adjudication. See LaFave, supra note 11, at 140-41, 149, 150. Although Professor LaFave advocates an unambiguous fourth amendment doctrine, see id. at 162, he has not embraced all of the Burger Court's bright-line rules. See 2 W. LAFAVE, supra note 16, at 152-60 (Supp. 1983) (criticizing the Belton bright-line rule).

207 New York v. Belton, 453 U.S. 454, 459 (1981).

208 Professor LaFave has conducted a similar inquiry and concludes that the Bellon rule is unnecessary, that it does not produce results approximating those produced by case-by-case analysis, and that it is somewhat ambiguous and subject to abuse. See $2 \mathrm{~W}$. LAFAVE, supra note 16, at 153-60 (Supp. 1983).

209 See generally supra notes 53-54, 179-85 and accompanying text.

210 See generally supra notes 186-88 and accompanying text.

211 See Michigan v. Thomas, 102 S. Ct. 3079, 3081 (1982) (per curiam) (applieation of automobile exception not dependent "upon a reviewing court's assessment of the likelihood in each case that the car would have been driven away . . ."); see generally supra notes 58-59 and accompanying text. 
subject to an automobile-exception search, the Court disregards the rationales for the automobile exception and allows warrantless searches of all containers.

The Gourt's departure from the exigency analysis of Carroll $v$. United States was not necessary to provide police with clear guidance. ${ }^{212} \mathrm{Al}-$ though the difficulty of the diminished privacy expectations analysis appears to necessitate a general application, ${ }^{213}$ the Carroll analysis does not. Strictly construed, Carroll requires two circumstances to validate warrantless vehicle or container searches: probable cause to search, and a threat that police would risk loss of evidence by seeking a warrant. ${ }^{214}$ Normally, determining the presence of these circumstances would not be difficult. Courts routinely determine whether probable cause to search exists. If a police department has sufficient resources to seize and hold vehicles pending issuance of search warrants, the threat to evidence does not exist. ${ }^{215}$ In the unlikely event ${ }^{216}$ that they could not prevent an arrestee or a confederate from moving or gaining access to a vehicle, ${ }^{217}$ police could conduct an immediate warrantless search. ${ }^{218}$ Thus, the two circumstances that Carroll required for warrantless searches, probable cause to search and a genuine threat to evidence, are sufficient guidelines for both courts and police.

Although the Court's recent decisions will eliminate some of the confusion surrounding the automobile exception, they fail to provide

212 Accord Note, supra note 21, 82 W. VA. L. REv. at 666 ("The original Carroll doctrine was very simple, clear, and most importantly, easy to apply.").

213 In the context of container searches, the Robbins plurality considered the privacy-expectations analysis "difficult if not impossible" to apply. Robbins v. California, 453 U.S. 420 , 426 (1981) (plurality opinion), overnuled on other grounds, United States v. Ross, 102 S. Ct. 2157 (1982).

214 See Comment, supra note 14, at 936 ("' $[\mathrm{T}] \mathrm{n}$ the absence of . . . true exigency . . . the warrantless search of a vehicle should be prohibited ...."). This approach would abolish an "automobile exception" authorizing disparate treatment of vehicles; the existence of exigency, not the presence of an automobile, would validate a warrantless search.

215 Police departments could be required to establish their general incapacity to seize and securely store vehicles. Factors such as past practice, manpower, existing facilities, and budget allocations would be relevant. Once a court determined that a police department was or was not eapable of seizure and storage, principles of collateral estoppel and judicial notice would aid future judicial determination. Initial determination would also provide sufficient guidance for police.

216 See supra note 186 and accompanying text.

217 For cases involving confederates of arrestees seeking to move vehicles, see Note, supra note 7 ; at 843 n.41.

218 If police have probable cause to search and to arrest a vehicle's occupant, they should conduct the arrest. Once police can lawfully detain the vehicle's occupant and seize the vehicle, there is no threat of mobility, and thus no need for a warrantless search. Probable cause to arrest and probable cause to search, however, do not always coexist. See $1 \mathrm{~W}$. LAFAvE, supra note 16 , at 443 . If police have probable cause to search a vehicle, but lack probable cause to arrest its occupant, the thrcat that the occupant may move the vehicle exists. This situation, however, is rare. See United States v. Ross, 102 S. Ct. 2157, 2178 n.6 (1982) (Marshall, J., dissenting). 
sufficient guidance to police. The applicability of the automobile exception in a number of contexts is still unclear. For example, the Court has not decided whether the exception applies to unoccupied, parked vehicles. ${ }^{219}$ Furthermore, the Court has not decided whether the exception allows warrantless searches of vehicles that commonly serve as residences, or whether police must consider such vehicles to be residences and seek warrants before searching them. ${ }^{220}$ Nor is the scope of the automobile exception altogether clear. The Court has not determined whether the exception extends to the person of a vehicle's occupant ${ }^{221}$ or to containers affixed to a vehicle's roof. ${ }^{222}$

Additional confusion may result from the Court's distinction between probable cause to search a vehicle and probable cause to search a container in a vehicle. If police have probable cause to search an entire vehicle, they can conduct warrantless searches of all containers located there. But if the probable cause focuses on a container, police must obtain a warrant to conduct the search. ${ }^{223}$ Probable cause is flexible, how-

219 See United States v. Ross, 102 S. Ct. 2157, 2159 (1982) ("we consider the extent to which police officers-who have legitimately stopped an automobile" may search compartments and containers within) (emphasis added); see also id. at 2174 n.1, 2175 n.2 (Marshall, J., dissenting) (Ross rule does not apply to unoccupied, parked vehicles). Some lower fcderal courts have applied the automobile exception to warrantless searches of unoccupied, parked vehicles. See, e.g., United States v. Matthews, 615 F.2d 1279 (10th Cir. 1980); United States v. Newbourn, 600 F.2d 452 (4th Cir. 1979); United States v. Milhollan, 599 F.2d 518 (3d Cir.), cert. denied, 444 U.S. 909 (1979); United States v. Robinson, 533 F.2d 578 (D.C. Cir. 1976); Haefeli v. Chernoff, 526 F.2d 1314 (1st Cir. 1975). The Ninth Gircuit, however, has referred to the automobile exception as the "moving vehicle exception," thus indicating that it will not apply the automobile exception to unoccupied, parked vehicles. See, e.g., United States v. Azhocar, 581 F.2d 735, 737 (9th Cir. 1978), cert. denied, 440 U.S. 907 (1979); United States v. Flickinger, 573 F.2d 1349, 1357 (9th Cir.), cert. denied, 439 U.S. 836 (1978).

If the automobile exception does not apply to unoccupied, parked vehicles, the courts must determine whether police may refrain from seeking a search warrant and instead wait for a vehicle's occupant to return, so that the automobile exception will apply. In Ross the car searched was unoccupied when police first saw it; only after they had left and later returned did the police see the defendant driving the car. $102 \mathrm{~S}$. Ct. at 2160.

220 Lower courts disagree about whether the automobile exception applies to mobile homes. Compare United States v. Wiga, 662 F.2d 1325, 1329 (9th Cir. 1981) (not applicable), cert. denied, 102 S. Ct. 1775 (1982) with United States v. Hudson, 601 F.2d 797, 800 (5th Cir. 1979) (applicable).

221 In United States v. Di Re, 332 U.S. 581, 587 (1948), the Court refused to extend the automobile exception to occupants of vehicles. In light of the recent expansion of the automobile exception, the precedential value of $D_{i} R e$ is suspect. In any event, the vitality of $D_{i}$ $R e$ is largely academic; because probable cause to search usually coexists with probable cause to arrest, United States v. Robinson, 414 U.S. 218 (1973) will in most cases authorize a warrantless search incident to arrest of the person of the arrested vehicle occupant. See supra notes 106-09 and accompanying text.

222 See United States v. Ross, 102 S. Ct. 2157, 2159 (1982) (Court addresses scope of a "search of compartments and containers within the vehicle. . .") (emphasis added).

223 By reaffirming Chadwick and Sanders to the extent that the probable cause in those cases focused on a specific container, the Ross Court distinguished probable eause to search a container in a vehicle from probable cause to search a vehicle generally and made clear that the automobile exception applies only when the latter exists. See Ross, $102 \mathrm{~S}$. Ct. at 2165-69. The Fifth Circuit recently failed to recognize the significance of this distinction when it held 
ever, and its focus may shift during a search. Police may begin a search with probable cause to search the entire vehicle because they believe that a particular container located somewhere in a vehicle contains contraband. When police locate the container, however, they have probable cause to search it alone. It is not clear whether the controlling probable cause is that existing when police commence the search, or that existing after police find the container. If the relevant probable cause is that existing when the search begins, the automobile exception would apply and police could search the container without a warrant; if the focus is on the time when the police discover the container, the exception would not apply and police would need a warrant to search the container.

Similarly, the distinction between compartments and containers in a vehicle, a distinction that the Ross Court did not discuss, may create confusion. Because the automobile exception only applies when police have probable cause to search a vehicle generally, not merely a specific container in a vehicle, the categorization of glove compartments and trunks has practical significance. If these compartments are treated as the equivalent of moveable containers, the automobile exception would not apply when police had probable cause to search a car trunk; police would need a warrant. But if these compartments are categorized as part of a vehicle, the automobile exception would apply; police with probable cause to search the glove compartment could open and search closed containers in the trunk. ${ }^{224}$

Thus, the Court's "bright-line" automobile exception fails to provide police with guidance in a number of circumstances. The methodology that the Court employs in its vehicle-search decisions is one reason for this failure. By severing the automobile exception from the rationales that support it, the Court has taken from police their only means of understanding whether and how the exception applies in new situations. As Justice Brennan notes, the Court "leaves open too many questions and, more important, it provides the police and the courts with too few

that Ross allowed federal agents to conduct warrantless automobile exception searches of bundles of marihuana that they seized from cars. See United States v. Rivera, 684 F.2d 308 (5th Cir. 1982). The agents had probable cause to search the bundles, not the cars; the automobile exception should not have applied.

For a discussion of problems posed by the distinction between probable cause to search vehicles and probable cause to search containers in vehicles, see 2 LAFAVE, supra note 16, at 174-76 (Supp. 1983).

224 The Court has distinguished vehicles from moveable containers on the basis of privacy expectations and the ease with which police can seize and store containers. See supra notes 68-75 and accompanying text. This two-pronged test is inadequate for conclusively categorizing trunks and glove compartments as either "containers" or "vehicles." These compartments are analogous to movcable containers in that people have high expectations that their contents will remain private; yet, they share with vehicles the difficulties of seizure and storage. 
tools with which to find the answers."225

Finally, the costs of the Burger Court's automobile exception, unwarranted privacy intrusions, exceed its benefits. The exception authorizes police officers to conduct warrantless searches of vehicles and containers when no need to protect evidence exists. Ross is a vivid example of the Court's willingness to allow warrantless searches despite considerable costs and minimal benefits. Having acknowledged that people have legitimate privacy expectations in containers and that police can easily seize and hold containers while seeking a warrant, ${ }^{226}$ the Ross Court nonetheless allows warrantless searches of containers that happen to be located in vehicles.

\section{The Search-Incident-to-Arrest Exception: Bright Line Rules Versus Immediate Control}

In New York v. Belton, the Court noted that the difficulty of applying the search-incident-to-arrest exception's "immediate control" test to vehicle searches had left lower courts in "disarray."227 The Court then concluded "that articles inside ... the passenger compartment of an automobile are in fact generally, even if not inevitably within" the arrestee's immediate control.228 In response, the Court adopted a "brightline" rule: an arresting officer may conduct a warrantless search of a vehicle's passenger compartment and any containers therein as a contemporaneous incident of an arrest. ${ }^{229}$ As was the case with the automobile exception, the Court's "bright-line" rule for the vehicle searchincident-to-arrest exception is unnecessary, unsuccessful, and an infringement on privacy interests.

Although the application of the "immediate-control" test to vehicle searches may have somewhat confused lower courts, the Court did not need to adopt the drastic Belton rule in response. Instead, the Court could have alleviated the confusion by requiring police officers to take reasonable precautions to prevent arrestees from gaining access to weapons or evidence in vehicles. Police can usually eliminate such a threat by removing an arrestee from his vehicle, closing the vehicle's doors, and either placing the arrestee in the police car or handcuffing him. ${ }^{230}$ In-

225 New York v. Belton, 453 U.S. 454, 469 (1981) (Brennan, J., dissenting). Although Bellon involved a search incident to arrest, and not an automobile-exception search, Justice Brennan's observation also applies to the Court's automobile exception.

226 Ross, 102 S. Ct. at 2166 n.16.

227 New York v. Belton, 453 U.S. 454, 459 n.1 (1981).

228 Id. at 459.

229 See id. at 460.

230 See 2 W. LAFAVE, supra note 16, at 158 (Supp. 1983); ff. United States v. Frick, 490 F.2d 666, 673 (5th Cir. 1973) (Goldberg, C.J., concurring and dissenting) ("Had the [arresting] agents nevertheless feared that [the arrestee] might reach exceptional levels of strength and cunning as a result of his desparate plight, surely the simple expedient of closing and locking the car door would have had the salutary effect of protecting the defendant's interests 
deed, "the 'difficulty' and 'disarray' the Belton majority alluded to has been more a product of the police seeing how much they could get away with . . . than their being confronted with inherently ambiguous situations." 231 Thus, a rule authorizing warrantless searches only when the arresting officers cannot reasonably prevent access to the interior of the arrestee's vehicle would both eliminate threats to police and evidence and alleviate whatever confusion the immediate-control test engendered. ${ }^{232}$

Additionally, the "bright-line" rule in Belton leaves a number of questions unanswered. It is unclcar whether the search-incident-to-arrest exception applies when the arrestee is handcuffed, ${ }^{233}$ when the arrestee has been outside the vehicle for a considerable length of time, ${ }^{234}$ or when the arrestce is no longer near the vehicle. ${ }^{235}$ The rule also fails to determine whether police may search locked suitcases, glove compartments, or trunks. ${ }^{236}$

Finally, the Court's vehicle search-incident-to-arrest exception unduly infringes on privacy interests. The Belton rule allows warrantless vehicle and container searches even when there is no threat to police or evidence $^{237}$ or a threat that police could easily eliminate by taking pre-

in privacy while guarding the safety of the officers and the integrity of the investigation from an irrational rampage."). If police took these precautions, the passenger compartment would not be "generally" or "inevitably" within the arrestee's immediate control.

2312 W. LAFAVE, supra note 16 , at 158 (Supp. 1983).

232 To govern those situations in which arresting officers cannot reasonably prevent access, the Court could either adopt a general rule authorizing warrantless searches of the passenger compartment or an "immediate-control" rule. For factors relevant to the latter, see 2 W. LAFAVE, supra note 16 , at 499-500.

233 Because a handcuffed arrestee usually cannot gain access to a passenger compartment, Belton should not apply. But see United States v. Enriquez, 675 F.2d 98, 99 (5th Cir. 1982) (per curiam) (Bellon applicable although defendant handcuffed); United States v. Collins, 668 F.2d 819, 821 (5th Cir. 1982); Government of V.I. v. Rasool, 657 F.2d 582, 585-92 (3d Cir. 1981); 2 W. LAFAVE, supra note 16, at 155 (Supp. 1983).

234 See New York v. Belton, 453 U.S. 454, $469-70$ (1981) (Brennan, J., dissenting); 2 W. LAFAVE, supra note 16, at 155 (Supp. 1983); $ø$. Preston v. United States, 376 U.S. 364, 368 (1964) (proscribing search incident to arrest "remote in time or place from the arrest").

235 See New York v. Belton, 453 U.S. 454, 469-70 (1981) (Brennan, J., dissenting); United States v. Musick, 534 F. Supp. 954, 963 (N.D. Cal. 1982) (Belton not applicable if arrestee not at scene); 2 W. LAFAvE, supra note 16, at 155-56 (Supp. 1983) (suggesting that Bellon limited to "on-the-scene" searches); cf. Preston v. United States, 376 U.S. 364, 368 (1964) (proscribing search incident to arrest "remote in time or place from the arrest").

236 Although the Belton Court held that the "bright-line" rule extends to closed containers in a passenger compartment, see 453 U.S. at 460-61 n.4, it did not discuss locked containers. Locked glove compartments and suitcases impede access more than closed glove compartments and suitcases do. Accord 2 W. LAFAvE, supra note 16, at 156-57 (Supp. 1983). An arrestee's access to the contents of a locked container or glove compartment in the vehicle is no greater than his access to the contents of a locked trunk. The Belton Court did not address the applicability of the search-incident-to-arrest exception to trunks. See 453 U.S. at $460-61$ n.4; United States v. Danhi, 525 F. Supp. 1201, 1203 (D. Mass. 1981) (Belton inapplieable to locked car trunk, especially when police have the keys).

237 See supra notes $151-58$ and accompanying text. 
cautions. ${ }^{238}$ The ease with which police can abuse the Belton rule imposes an additional cost. Because the search-incident-to-arrest exception for vehicles allows warrantless searches incident to any custodial arrest, police may use traffic violations or other minor arrests as pretexts to conduct extensive searches of people, vehicles, and containers. ${ }^{239}$

\section{G. An Explanation of the Vehicle Search Decisions: An Attack on the Exclusionary Rule}

The Burger Court's treatment of warrantless vehicle searches is difficult to understand. Having abandoned exigency-based approaches, the Court has adopted rules that lack substantive support, fail to provide guidance to police and courts, and unnecessarily infringe on privacy interests. Perhaps the only clue to the Court's motivation for these decisions is a discernible trend in the decisions: expansion of police power to conduct warrantless searches. ${ }^{240}$

This trend arguably betrays hostility toward the requirement that police obtain a warrant before conducting searches and seizures. ${ }^{241}$ On closer examination, however, this explanation is not plausible. Recent cases indicate that a majority of the Court continues to support the warrant requirement. ${ }^{242}$

238 See supra notes 230-32 and accompanying text.

239 See Robbins v. California, 453 U.S. 420, 450-51 (1981) (Stevens, J., dissenting); 2 W. LAFAVE, supra note 16, at 139-40; LaFave, supra note 11 , at 150-61. Even if a police officer conducts an arrest as a pretext to conduct a search incident to arrest of a vehicle, its passengers, or its contents, the search is constitutional, despite the offieer's motives, if the arrest is lawful. See Scott v. United States, 436 U.S. 128 (1978) (objective circumstances, not state of mind, control constitutionality of search).

240 The Burger Court expanded the automobile and the search-incident-to-arrest exceptions in Michigan v. Thomas, 102 S. Ct. 3079 (1982) (per curiam); United States v. Ross, 102 S. Ct. 2157 (1982); New York v. Belton, 453 U.S. 454 (1981); Colorado v. Bannister, 449 U.S. 1 (1980) (per curiam); Texas v. White, 423 U.S. 67 (1975) (per curiam); Cardwell v. Lewis, 417 U.S. 583 (1974) (plurality opinion); Gustafson v. Florida, 414 U.S. 260 (1973); United States v. Robinson, 414 U.S. 218 (1973); and Chambers v. Maroney, 399 U.S. 42 (1970). The Supreme Court's decision in United States v. Ross, 102 S. Ct. 2157 (1982) "overruled" Robbins v. California, 453 U.S. 420 (1981) (plurality opinion), see supra note 127 and accompanying text, and interpreted Arkansas v. Sanders, 442 U.S. 753 (1979) to require police to obtain warrants only when the automobile exception is inapplicable, see supra note 128 and accompanying text; as a result, Coolidge v. New Hampshire, 403 U.S. 433 (1973) (plurality opinion) is the only Burger Court decision that restricts police officers' ability to conduct warrantless vehicle searches. See supra notes $45-49$ and accompanying text. The Court has also upheld warrantless vehicle searches for reasons other than the automobile and search-incident-toarrest exceptions. See, e.g., Unitcd States v. Martinez-Fuerte, 428 U.S. 543 (1976) (border search); Cady v. Dombrowski, 413 U.S. 433 (1973) (warrantless search constitutional as part of police caretaking function). But see, e.g., United States v. Ortiz, 422 U.S. 891 (1975) (fourth amendment restricts ability to conduct border searches without probable eause); United States v. Brignoni-Prince, 422 U.S. 873 (1975) (border search based on suspicion ereated by vehicle occupant's ancestry unconstitutional).

241 See supra note 15.

242 See, e.g., United States v. Ross, 102 S. Ct. 2157, 2172 (1982); øf. Payton v. New York, 445 U.S. 573 (1980) (arrest warrant). 
The trend may also indicate that the Court has concluded that real property is entitled to greater fourth amendment protection than is personal property. ${ }^{243}$ Arguably, the Court is willing to require that police obtain a warrant only in those cases in which they search real property. Indeed, a plurality of the Court has construed Coolidge v. New Hampshire as providing enhanced fourth amendment protection to vehicles located on private property. ${ }^{244}$ Furthermore, "inherent. mobility," one of the Court's justifications for the automobile exception, ${ }^{245}$ distinguishes real property, which is not inherently mobile, from personal property, which is mobile. Although the Court may eventually conclude that the fourth amendment warrant requirement protects only real property, ${ }^{246}$ it has yet to reach such a conclusion. Indeed, recent decisions mandating warrant-requirement protection for containers not subject to the automobile

243 Justice Blackmun has argued for diminished warrant requirement protection for personal property: "[A] warrant [should] not [be] required to seize and search any movable property in the possession of a person properly arrested in a public place." United States v. Chadwick, 433 U.S. 1, 19 (1977) (Blackmun, J., dissenting).

244 See Cardwell v. Lewis, 417 U.S. 583, 593 (1974) (plurality opinion).

245 See supra notes 58-59 and accompanying text.

246 There are indications that the Supreme Court may eventually create a "container exception" to the fourth amendment warrant requirement. Taken in conjunction with the automobile exception, a "container exception" would limit warrant requirement protection to real property. The Court's desire to establish "bright-line" rules may lead to such an exception. Although police with probable cause to search luggage clearly must obtain a warrant to do so, see Arkansas v. Sanders, 442 U.S. 753 (1979), limiled, United States v. Ross, 102 S. Ct. 2157 (1982); United States v. Chadwick, 433 U.S. 1 (1977), it is not clear whether the warrant requirement protects less "worthy" containers. When the same issue arose with respect to the application of the automobile exception to containers located in vehicles, the resulting dispute among members of the Court, see supra notes 77-89 and accompanying text, and disarray in lower courts, see, e.g., cases cited in United States v. Ross, 655 F.2d 1159, 1174-76 nn. 3 \& 4 (D.C. Cir. 1981) (Tamm, J., dissenting), rev'd, 102 S. Ct. 2157 (1982), led the Supreme Court to allow warrantless searches of all containers in vehicles that are subject to an automobile-exception search. See United States v. Ross, 102 S. Ct. 2157 (1982). In order to avoid similar confusion with respect to warrantless searches of containers that are not located in vehicles, the Court either may adopt a "container exception" or may apply the warrant requirement to all containers. See id. at 2171 (Court refuses to distinguish worthy from unworthy containers). A further source of confusion, and thus an impetus for a "brightline" rule allowing warrantless container searches, is the definition of "containers." See, e.g., United States v. Weber, 668 F.2d 552, 561-62 (1st Cir. 1981) (rolled-up rainslicker containing walkie-talkie is a container), cert. denied, 102 S. Ct. 2904 (1982); United States v. Hodge, 519 F. Supp. 654, 656 (E.D. Tenn. 1981) (blanket not a container); $f$. New York v. Belton, 453 U.S. 454,460 n.4 (1981) (definition of container for purposes of search-incident-to-arrest exception).

Whether or not the Court adopts a "container exception," see infa note 247 and accompanying text, the Court's search-incident-to-arrest analysis in New York v. Belton, 453 U.S. 454 (1981) may lead to expanded police power to conduct warrantless searches of containers in the possession of arrestees. See supra notes 151-58 and accompanying text. In cases not involving vehicles, and in which arrestees at the scene of the arrest lack immediate control over containers, lower federal courts have cited to Bellon to uphold warrantless searches as incident to arrest. See, e.g., United States v. Brown, 671 F.2d 585, 587 (D.C. Cir. 1982) (per curiam); United States v. Mefford, 658 F.2d 588, $591-93$ (8th Cir. 1981), cert. denied, 455 U.S. 1003 (1982). See generally Note, supra note 16, 9 FORDHAM URB. L.J. at 206-11. 
exception indicate that the Court is not yet willing to distinguish between real and personal property when applying the fourth amendment. ${ }^{247}$

The Burger Court's vehicle-search decisions can best be explained as a hostile response to the exclusionary rule. Rather than apply the rule as a sanction for violations of the fourth amendment, the Court denies the existence of fourth amendment rights by expanding exceptions to the warrant requirement. Both the Burger Court's fourth amendment decisions ${ }^{248}$ and opinions of individual justices demonstrate the Court's disapproval of the exclusionary rule. ${ }^{249}$ Indeed, several Justices ${ }^{250}$ and a

247 See Arkansas v. Sanders, 442 U.S. 753 (1979), limited, United States v. Ross, 102 S. Ct. 2157 (1982); United States v. Chadwick, 433 U.S. 1, 7 (1977) ("We do not agree that the Warrant Clause [of the fourth amendment] protects only dwellings . . . .").

248 See, c.g., United States v. Havens, 446 U.S. 620, 627 (1980) (illegally seized evidence admissible to impeach defendant's cross-examination testimony); Michigan v. DeFillipio, 443 U.S. 31, 39-40 (1979) (evidence seized in good faith pursuant to city ordinance admissible, although ordinance held unconstitutional on appeal); Rakas v. Illinois, 439 U.S. 128, 134 (1978) (no violation of fourth amendment if individual subject to warrantless vehicle search lacks possessory interest or control over vehicle or objects discovered in search); Scott v. United States, 436 U.S. 128, 138 (1978) ("[T] he fact that the officer does not have the state of mind which is hypothecated by the reasons which provide the legal justifieation for the officer's action does not invalidate the action taken as long as the circumstances, viewed objectively, justify that action.'); Stone v. Powell, 428 U.S. 465, 494 (1976) (federal district court cannot consider habeas corpus petition of state prisoner who had full and fair opportunity to litigate fourth amendment claim in state courts); United States v. Janis, 428 U.S. 433, 454 (1976) (evidence obtained by unconstitutional means admissible to prove bookmaking activity in civil tax assessment suit); United States v. Calandra, 414 U.S. 338, 350-51 (1974) (exclusionary rule not applicable to grand jury proceedings). For an examination of the Burger Court's treatment of the exclusionary rule, see, e.g., Burkoff, The Court That Devoured The Fourth Amendment: The Triumph of an Inconsistent Exclusionary Doctrine, 58 OR. L. REv. 141 (1979); Saltzburg, Foreword: The Flow and Ebb of the Constitutional Criminal Procedure in the Warren and Burger Courts, 69 Geo. L.J. 151, $191-97$ (1980); Schrock \& Welsh, Up From Calandra: The Exclusionary Rule as a Constitutional Requirement, 59 MiNN. L. REv. 251 (1974). On the exclusionary rule in general, see, e.g., the studies and articles cited in United States v. Janis, 428 U.S. 433, $447 \mathrm{n} .18$ (underlying policy), $499 \mathrm{n} .21$ (alternatives), $450 \mathrm{n} .22$ (effectiveness) (1976); Ball, Good Faith and the Fourth Amendment: The "Reasonable" Exception to the Exclusionary Rule, 69 J. CRIM. L. \& CRIminology 635 (1978); Canon, The Exclusionary Rule: Have Critics Proven that it Doesn't Deter Police?, 62 Judicature 398 (1979); Kamisar, Is the Exclusionary Rule an "Illogical" or "Unnatural" Interpretation of the Fourth Amendment?, 62 JUDICATURE 66 (1978); Schlesinger, The Exclusionary Rule: Have Proponents Proven that it is a Deterrent 10 Police?, 62 JUDICATURE 404 (1979); Wilkey, The Exclusionary Rule: Why Suppress Valid Evidence?, 62 JUDICATURE 214 (1978). See generally 1 W. LAFAVE, supra note 16, at 3-219 (1978).

249 See, e.g., Robbins v. California, 453 U.S. 420, 437 (1981) (Rehnquist, J., dissenting) (exclusionary rule "imposes a burden out of all proportion to the Fourth Amendment values which it seeks to advance"; Mapp should be overruled), ovemuled, United States v. Ross, $102 \mathrm{~S}$. Ct. 2147 (1982); Stone v. Powell, 428 U.S. 465, 538 (1976) (White, J., dissenting) ("[T]he rule should be substantially modified so as to prevent its application in those many circumstances where the evidence at issue was seized by an officer acting in the good-faith belief that his conduct comported with existing law and having reasonable grounds for this belief."); Coolidge v. New Hampshire, 403 U.S. 443, 510 (1971) (opinion of Blackmun, J.) (agreeing with portion of Justice Black's opinion "which [was] to the effect that the Fourth Amendment supports no exclusionary rule"); Bivens v. Six Unknown Agents, 403 U.S. 388, 411-24 (1971) (Burger, C.J., dissenting) (exclusionary rule "conceptually sterile and practically ineffective"; goal of deterrence "hardly more than a wistful dream").

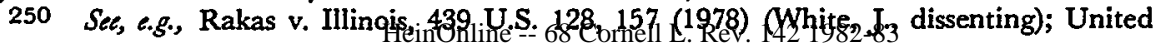


number of commentators ${ }^{251}$ have viewed the Court's recent decisions limiting fourth amendment rights and defendants' ability to assert them as covert attacks on the exclusionary rule. ${ }^{252}$

The vehicle-search decisions have provided the Court with an excellent means of indirectly attacking the exclusionary rule. The absence of substantial authority construing either the automobile exception or the search-incident-to-arrest exception in the context of vehicle searches has allowed the Burger Court to expand these exceptions without explicitly overruling previous decisions. ${ }^{253}$ Furthermore, the manner in which

States v. Peltier, 422 U.S. 531, 561-62 (1975) (Brennan, J., dissenting) (majority is engaged in "slow strangulation of the [exclusionary] rule").

251 Set Burkoff, supra note 248, at 159 ("Some commentators have suggested that the aim of the Burger Court in revamping the doctrinal basis of the exclusionary rule is to emasculate the rule de facto by systematically narrowing its range of application."); see also Note, supra note $16,82 \mathrm{~W}$. VA. L. REv, at 638 (attack on exclusionary rule may explain expansion of "automobile exception").

252 United States v. Calandra, 414 U.S. 338 (1974), cast doubt on the vitality of the exclusionary rule. In Calandra, the Court characterized the rule as a judicially created remcdy aimed at deterring police violations of constitutional rights, rather than as a constitutional right of the party whose rights have been violated. See id. at 348; see also United States v. Peltier, 422 U.S. 531 (1975).

By labeling the rule a mere deterrent, the Calandra Court invited a dual attack on the rule. First, as a deterrent, the rule's continued existence depends upon the absence of substitutes. See Monaghan, The Supreme Court, 1974 Term-Foreword: Constitutional Law, 89 HARv. L. REv. 1, 6-8 (1975) (after Calandra and Peltier, Court cannot impose exclusionary rule upon a state providing a viable alternative). Calandra indicated that other rules that deter police misconduct are the constitutional equivalents of the exclusionary rule. See 414 U.S. at 347-48. Second, as a deterrent, arguably the rule should not apply when application of the rule will not deter police misconduct. See, e.g., Stone v. Powell, 428 U.S. 465, 493-94 (1976) (minimal deterrent value of applying exclusionary rule in a collateral proceeding does not justify cost of application). Some courts have already refused to exclude evidence when police, acting reasonably and in good faith, violate the fourth amendment. See, e.g., United States v. Williams, 622 F.2d 830, 840-48 (5th Cir. 1980) (per curiam), cert. denied, 499 U.S. 1127 (1981); United States v. Nolan, 530 F. Supp. 386, 396-99 (W.D. Pa. 1981); People v. Adams, 53 N.Y.2d 1, 910, 422 N.E.2d 537, 541, 439 N.Y.S.2d 877, 881 (1981) (reasonable, good-faith belief that individual consented to search). The Supreme Court recently granted certiorari to determine whether the exclusionary rule "should to any extent be modified, so as, for example, not to require the exclusion of evidence obtained in the reasonable belief that the search and seizure at issue was consistent with the Fourth Amendment." Illinois v. Gates, cert. granted, $103 \mathrm{~S}$. Ct. 436 (1982).

253 Thus, the Bellon majority was able to claim that "[o]ur holding today does no more than determine the meaning of Chimel's principles in this particular and problematic content [sic]." New York v. Belton, 453 U.S. 454, 460 n. 3 (1981). The dissenters claimed, on the other hand, that the holding was an "extreme extension of Chimel," id. at 472 (White, J., dissenting) and did "a grcat disservice" to stare decisis, id. at 469 (Brennan, J., dissenting). Although it did overrule Robbins and limit Sanders, the Ross Court contended that it did not violate stare decisis:

Our decision today is inconsistent with the disposition in Robbins v. Califomia and with the portion of the opinion in Arkansas $v$. Sanders on which the plurality in Robbins relied. Nevertheless, the doctrine of stare decisis does not preclude this action. Although we have rejeeted some of the reasoning in Sanders, 
the "automobile exception" is articulated makes it conducive to diminished fourth amendment protection. Most exceptions to the warrant requirement are phrased in terms of their justifications; for example, a police officer may conduct a warrantless search under the "hot pursuit" and "consent" exceptions only because the officer is in hot pursuit at the time of the search or because the arrestee consents to the search. Expanding such exceptions beyond their justifications is usually diffcult. ${ }^{254}$ In contrast, the "automobile exception" is not phrased in terms of its justification; instead, it indicates where, not why, a warrantless search may take place. The Court, therefore, has been able to ignore the exigency rationale that originally justified the exception. Additionally, the Court's view that vehicles do not warrant full fourth amendment protection has contributed to the expansion of the search-incident-toarrest exception as it applies to vehicles. ${ }^{255}$

\section{CONCLUSION}

The Supreme Court's reluctance to apply the exclusionary rule has led it to expand exceptions to the warrant requirement in vehicle-search cases. This expansion has not only left fourth amendment rights unprotected, but also has failed to provide sufficient guidance for lower courts and police. ${ }^{256}$ The Court is thus left with an unwanted but relatively intact exclusionary rule and an unprincipled and unsatisfactory approach to warrantless vehicle searches. Furthermore, if the Court or the Congress eventually accepts or establishes alternatives to the exclusion-

we adhere to our holding in that case; although we reject the precise holding in Robbins, there was no Court opinion supporting a single rationale for its judgment and the reasoning we adopt today was not presented by the parties in that case.

United States v. Ross, 102 S. Ct. 2157, 2172 (1982).

254 Although the Court has abandoned the exigency-based rules in vehicle-search cases, it still requires exigency for most of the other exceptions to the warrant rcquirement. See Comment, supra note 14, at 948; see also Note, supra note 16, 82 W. VA. L. REV. at 639 ("[T]he warrant requirement is being strictly construed in many non-vehicle cases.').

255 For example, courts have even invoked the reasons for the "automobile exception" to justify warrantless vehicle searches under the search-incident-to-arrest cxception. See, e.g., United States v. Frick, 490 F.2d 666, 669-70 (5th Cir. 1973) (while applying the search-incident-to-arrest exception, court relies upon mobility of a vehicle and existence of probable cause to search, two justifications of the automobile exception), cert. denied, 419 U.S. 831 (1974).

256 Ironically, any confusion created by the Court will serve as a further basis for attacking the exclusionary rule:

If the Court's decisions provided clearer guidance to police, fewer suppression issues would arise, and the Court probably would not be concerned about the exclusionary rule. Unfortunately, the Court itself has produced confusion about the scope of [fourth amendment rights] and then has blamed its ensuing problems on the remedy it has chosen to protect the right.

Saltzburg, supra note 248 , at 193 n.301. The Court has also used the confusion to extend the exceptions to the warrant requirement by claiming a need for clear guidelines. See, e.g., New York v. Belton, 453 U.S. 454, 458 (1981). 
ary rule, ${ }^{257}$ the privacy rights of vehicle users will remain unprotected because of the Court's indirect attack on the rule. ${ }^{258}$ If the Court doubts the constitutional basis or efficacy of the exclusionary rule, it should either abolish or modify it directly, rather than distort fourth amendment doctrines to avoid applying the rule. ${ }^{259}$

Steven D. Clymer

257 See supra note 8 (Supreme Court consideration of good-faith exception to the exclusionary rule); see generally $1 \mathrm{~W}$. LAFAVE, supra note 16, at 30-39 (discussion of alternatives to the exclusionary rule).

258 See, e.g., Doyle v. Wilson, 529 F. Supp. 1343 (D. Del. 1982) (civil rights plaintiff denied relief in lawsuit under 42 U.S.C. $\$ 1983$; automobile exception authorized police conduct).

259 See Rakas v. Illinois, 439 U.S. 128, 157 (1978) (White, J., dissenting) ("If the Court is troubled by the practical impact of the exclusionary rule, it should face the issue of that rule's continued validity squarely instead of distorting other doctrines in an attempt to reach what are perceived as the correct results in specific cases."). 